УДК 354:327

DOI https://doi.org/10.32836/2310-9653-2020-3.17

В. Ф. Загурська-Антонюк, кандидат політичних наук, доцент, доцент кафедри економічнї безпеки, публічного управління та адміністрування Державного університету «Житомирська політехніка»

Д. О. Грицишен, доктор економічних наук, профресор, декан фракультету публічного управління та права Державного університету «Житомирська політехніка»

\title{
УПРАВЛІННЯ НАЦІОНАЛЬНОЮ ЕНЕРГЕТИЧНОЮ БЕЗПЕКОЮ В УМОВАХ ГЛОБАЛІЗАЦІї СУЧАСНОГО СВІТУ
}

У сучасному глобалізованому світі немає загальновизнаного розуміння поняття енергетичної безпеки. У глобальному контексті енергетична безпека означає не тільки запобігання конфліктів у боротьбі за енергетичні ресурси між постачальниками й споживачами, усередині групи країн-постачальників і усередині групи країн-споживачів, але й розширення доступу до енергетичних ресурсів.

Глобалізащія енергетичних проблем і системи енергетичної безпеки, націленої на їхнє рімення, потребує міжнародного механізму, який би враховував саме глобальний аспект енергетичного виміру. Глобальний аспект стосується підходу до енергетичних ресурсів не тільки як до товару, але й як до однієї з основ економічного та гуманітарного розвитку світової спільноти. Енергетика як, приміром, й екологія, - ие сфера, проблеми й завдання якої стосуються умов життя людини в кожній країні. Міжнародний механізм глобальної енергетичної безпеки міг би забезпечити легітимний $і$ авторитетний арбітраж як різних підходів до енергетичних проблем, так $і$ спірних випадків в енергетичній сфері. Наявність вільних, конкурентних $і$ відкритих ринків має життєво важливе значення для ефективного функціонування глобальної енергетичної системи. Зусилля по підвищенню прозорості, посиленню й розширенню верховенства права, створенню й зміцненню передбачуваних, ефективних режсимів оподатковування й регулювання, - все це відіграє істотну роль у забезпеченні глобальної енергетичної безпеки. Знижуючи рівень невизначеності, иі зусилля сприяють кращому розумінню енергетичного ринку, а значить - прийняттю більше зважених інвестииійних рішень і підвищенню конкурентоспроможності. Для безперебійного функціонування світових енергетичних ринків необхідний також регулярний і своєчасний обмін інформаиією між всіма ринковими гравиями. Формуванню ефективних енергетичних ринків сприяє прозорість і передбачуваність енергетичної політики й режимів регулювання на рівні окремих держав.

Істотний внесок у глобальну енергетичну безпеку вносить прозорість, стабільність і передбачуваність національних систем регулювання. Проблема глобальної енергетичної безпеки виникла нині як нагальна необхідність надійного забезпечення світової економіки всіма видами енергії без надмірної шкоди довкіллю і за иінами, щяо відображають основні економічні принциини.

Ключові слова: глобалізаџія, енегетична безпека, енергетичний ринок, управління нащіональною безпекою.

\section{F. Zagurska-Antoniuk, D. O. Gritsichen. Management of national energy security in the conditions of globalization} of the modern world

In today's globalized world, there is no generally accepted understanding of the concept of energy security. In a global context, energy security means not only preventing conflicts in the struggle for energy resources between suppliers and consumers, within the group of supplier countries and within the group of consumer countries, but also expanding access to energy resources.

The globalization of energy problems and the energy security system aimed at solving them requires an international mechanism that takes into account the global aspect of the energy dimension. The global aspect concerns the approach to energy resources not only as a commodity, but also as one of the foundations of economic and humanitarian development of the world community. Energy, like, for example, ecology, is an area whose problems and tasks relate to the living conditions of people in each country. An international mechanism for global energy security could provide legitimate and authoritative arbitration of both different approaches to energy issues and controversial cases in the energy sector. Having free, competitive and open markets is vital to the efficient functioning of the global energy system. Efforts to increase transparency, strengthen and expand the rule of law, and create and strengthen predictable, effective taxation and regulation regimes all play a significant role in ensuring global energy security. By reducing uncertainty, these efforts contribute to a better understanding of the energy market, and thus to more prudent investment decisions and increased competitiveness. Regular and timely exchange of information between all market players is also necessary for the smooth functioning of global energy markets. Transparency and predictability of energy policies and regulatory regimes at the level of individual states contribute to the formation of efficient energy markets.

Transparency, stability and predictability of national regulatory systems make a significant contribution to global energy security. The problem of global energy security has arisen today as an urgent need to reliably provide the world economy with all types of energy without undue harm to the environment and at prices that reflect basic economic principles.

Key words: globalization, energy security, energy market, national security management.

(C) В. Ф. Загурська-Антонюк, Д. О. Грицишен, 2020 
Вступна частина. Поняття «енергетична безпека», що закріпилося у зв’язку з нафтовим ембарго 1973 р., трактувалося спочатку як енергетична самодостатність країни, тобто можливість її надійного доступу до достатньої за обсягом і прийнятної за ціною енергії. Після адаптації світової економіки до наслідків тієї нафтової кризи здавалося, що проблеми енергопостачання вцілому успішно розв'язуються. Проблема різко ускладнилася якісною зміною світової економіки й енергетики: вони стали набагато інтегрованішими і по суті глобальними. Багаторазове зростання міжнародної торгівлі енергією (вдвічі із 80-х рр. XX ст. по 20-ті рр. XXI ст.) та їі частки в забезпеченні енергоспоживання посилили взаємозалежність учасників енергетичного ринку і вивели питання енергобезпеки із рівня національної безпеки на рівень транснаціональний - глобальний рівень.

Неможливість розвитку економіки без енергетики загострює необхідність щодо подолання цієї проблеми на глобальному рівні. Безперечно, що вуглеводні ресурси, які є базовими в сучасних умовах, будуть вичерпані через певний час. Відповідно, країни-постачальники, так само, як і всі інші, будуть поступово змінювати структуру свого паливно-енергетичного балансу, приділяючи усе більшу увагу альтернативним джерелам енергії. Збереження ситуації, за якої 2 млрд. людей не мають доступу до енергетичних ресурсів, загрожує гуманітарними катастрофами, зростанням напруженості у світі, появою нових конфліктів.

За прогнозами сучасних аналітиків, світове енергоспоживання може зрости на третину за найближчі 15 років, і приблизно на 45\% - у майбутньому двадцятилітті. Ситуація на світовому ринку характеризується такими обставинами: різкий ріст потреб азіатських країн, що розвиваються, в енергоресурсах (до 45\% перспективного приросту світового попиту на нафту) [7]; збільшення розриву між обсягами споживання й обсягами виробництва газу в розвинених економічних країнах; недостатність нафтопереробних і транспортних потужностей і обмеженість додаткових потужностей по видобутку нафти; недостатня транспарентність світової торгівлі енергоресурсами. Усі ці обставини визначають проблему енергетичної безпеки як найбільш гостру і пріоритетну щодо вирішення.

Глобальний характер загроз енергетичній безпеці та їхні наслідки зумовлюють мету даної статті, у якій здійснюється аналіз управління національною енергетичною безпекою в глобальних умовах розвитку сучасного світу та динаміка первинного енергоспоживання у світі.

У зв'язку з вищесказаним за останніх 20 років XXI століття зацікавлення щодо дослідження енергетичної безпеки значно зросло. Дана проблематика розглядається в контексті дослідження глобальної безпеки у працях таких учених і дослідників, як: Бодрук О., Гальчинський А. [2], Джердж С. [6], Калетськи А. [8], Ожеван М., Парахонський Б., Прейгер Д., Сагхір Дж. [9], Тодоров І. [4], Федуняк С. [5], Фуршев В. [6].

Виклад основного матеріалу. Глобалізація енергетичних проблем і системи енергетичної безпеки, націленої на їхнє рішення, потребує міжнародного механізму, який би враховував саме глобальний аспект енергетичного виміру. Глобальний аспект стосується підходу до енергетичних ресурсів не тільки як до товару, але й як до однієї з основ економічного й гуманітарного розвитку світової спільноти. Енергетика як, приміром, й екологія, це сфера, проблеми й завдання якої стосуються умов життя людини в кожній країні.

Міжнародний механізм глобальної енергетичної безпеки міг би забезпечити легітимний і авторитетний арбітраж як різних підходів до енергетичних проблем, так і спірних випадків в енергетичній сфері. Наявність вільних, конкурентних і відкритих ринків має життєво важливе значення для ефективного функціонування глобальної енергетичної системи. Зусилля по підвищенню прозорості, посиленню й розширенню верховенства права, створенню й зміцненню передбачуваних, ефективних режимів оподатковування й регулювання, - все це відіграє істотну роль у забезпеченні глобальної енергетичної безпеки. Знижуючи рівень невизначеності, ці зусилля сприяють кращому розумінню енергетичного ринку, а значить - прийняттю більше зважених інвестиційних рішень і підвищенню конкурентоспроможності. Для безперебійного функціонування світових енергетичних ринків необхідний також регулярний і своєчасний обмін інформацією між всіма ринковими гравцями. Формуванню ефективних енергетичних ринків сприяє прозорість і передбачуваність енергетичної політики й режимів регулювання на рівні окремих держав.

Істотний внесок у глобальну енергетичну безпеку вносить прозорість, стабільність і передбачуваність національних систем регулювання. Їхньому вдосконалюванню могли б сприяти відповідні міжнародні угоди, такі, як Європейська енергетична хартія й зусилля країн іiі учасниць по зміцненню міжнародного співробітництва в області енергетики.

Чинники, що актуалізували проблеми міжнародної енергетичної безпеки:

1. Різке скорочення наявних резервних потужностей в умовах швидкого росту споживання енергоресурсів (особливо вуглеводнів). Відставання темпів відкриття й освоєння нових родовищ від зростання споживання вуглеводнів пов'язано, насамперед, із недостатністю відповідних інвестицій.

2. Збереження на низькому рівні видобутку нафти в Іраку. Експерти й керівники нафтових компаній вважають, що зростання видобутку нафти ні в Іраку, ні в Казахстані не зможе компенсувати достатньою мірою падіння видобутку в інших країнах виробниках цього виду сировини.

3. Нестабільність світових цін на нафту за збереження загального високого рівня. Обсяги грошових операцій на віртуальних ринках торгівлі нафтою значно перевищують ті, що мають місце на ринку фізичному. 
4. Розвиток альтернативних джерел енергії з технологічної й економічної точок зору явно відстало від темпів зростання споживання енергії.

5. Посилення конкуренції за доступ до джерел енергоносіїв як між суб’єктами бізнесової діяльності (відповідними компаніями), так і державами. Йдеться про конкуренцію між найбільш впливовими «центрами сили» світової економіки й світової політики - як тими, хто вже протягом десятиліть затвердився в цій якості (США, (C, Японія), так і тими, хто зробив саму серйозну заявку на завоювання високого місця у світовій економічній і політичній ієрархії в останні 5-10 років (насамперед Китай і Індія). У 2007 році Китай вийшов на друге місце у світі у споживанні нафти, обійшовши Японію. При цьому розрив між добутою в КНР нафтою та споживанням цієї сировини оцінюється приблизно в 130 млн. тон. Індія, яка залежить від імпорту енергоносіїв на 70\% обійшла зі споживання нафти Південну Корею й ФРН - найбільшого споживача нафти серед країн СС [8].

6. Предметом серйозних міждержавних розбіжностей (які можуть трансформуватися в конфлікти) є проблеми виборів маршрутів нафто і газопроводів. При виборі цих маршрутів ураховується не тільки їх безпосередня економічна обгрунтованість і ступінь політичної стабільності в країнах, по території яких пролягає маршрут, але й так звані геополітичні міркування. При цьому вартість транспортування ресурсів часто відступає на другий план.

7. Серйозні конфлікти можуть виникати у трикутнику «виробник - споживач - транзитна країна». Приклад тому - кризи в російсько-українських відносинах, що, сподіваємось, відійшли в минуле.

8. Наближення до вичерпання ресурсів, різке зростання собівартості їх видобування та транспортування в Pociï.

9. Зростання конфліктності між низкою країн щодо спірних територій, на яких є потенційно значимі обсяги енергетичної сировини.

10.Спільні інтереси в постачанні енергоносіями можуть сприяти розвитку співробітництва між країнами-антагоністами, зниженню напруженості в їхніх відносинах. (Про це свідчить взаємодія Індії та Пакистану в питанні про будівництво газопроводу з Ірану в ці дві країни, потенційно далі - до Китаю).

11.Забезпечення безпеки шляхів транспортування вуглеводнів системою заходів політико-військового порядку.

12.Зростання ролі екологічних факторів (шкідливі викиди з боку енергетичних підприємств, аварії при транспортуванні енергоресурсів, завдання збитків навколишньому середовищу в процесі переробки енергетичних ресурсів, споживання енергетикою двох третин всієї свіжої води, що йде на потреби промисловості).

Зокрема, найгострішим викликом для глобальної енергетичної безпеки є загроза відставання пропозиції щодо енергозабезпечення від зростання енергоспоживання, яка зумовлена передовсім небезпекою виникнення чергової (третьої) хвилі зростання світового енергоспоживання. Попередня довга хвиля отримала розвиток наприкінці 1940-х років і завершилася в середині 1990-х, збільшивши світове енергоспоживання майже в 5 разів і на душу населення - практично вдвічі [4; 5]. Ї̈і закінчення було пов'язане зі стабілізацією середнього рівня енергоспоживання на душу населення у світі від початку 80-х років XX ст. Це пояснюється скороченням загального i на душу населення енергоспоживання в колишніх країнах планової економіки і зниженням на душу населення енергоспоживання у країнах, що входять в Організацію економічного співробітництва і розвитку, при відносно помірному зростанні на душу населення енергоспоживання в країнах, що розвиваються. Проте останніми роками перші два чинники перестали діяти, а найбільші з країн, що розвиваються, - Китай та Індія - все швидше нарощують споживання на душу населення. На азіатські країни, що активно розвиваються, припадає близько третини загального перспективного приросту світового енергоспоживання і до 45\% приросту попиту на нафту. Випереджальними темпами збільшується споживання енергії в Африці та Латинській Америці. Навіть у Свропейському союзі поновилося зростання енергоспоживання на душу населення. Це вже загрожує новим циклом збільшення енергоємності світового ВВП. Результатом вже стало від 2000-х років прискорення зростання світового енергоспоживання, зумовлене динамічнішим економічним розвитком і збільшенням ролі енергії в житті людства. Чисельність населення Землі, як відомо, наближається до 7 млрд. і продовжує збільшуватися. Зростання рівня життя і народонаселення спричиняє неухильний підйом споживання енергетичних ресурсів, незважаючи на впровадження нових технологій і енергоощадних тенденцій. Звідси - прогнозоване значне зростання потреби в енергії i, отже, в інвестиціях для створення ефективної системи енергопостачання. За прогнозами Міжнародного енергетичного агентства, до 2030 р. попит на енергію збільшиться в півтора рази [1], домінуючу роль, як і раніше, відіграватимуть вуглеводні - іхня частка збережеться на рівні 80-81\% при незначному зменшенні частки нафти ( 335 до 34\%). Інша небезпека полягає в уповільненні зростання пропозиції енергії поки що не через загальний брак енергоресурсів, а внаслідок відносного скорочення сфери докладання сил і засобів із нарощування їх виробництва. Це зумовлено негативним ефектом масштабу в природокористуванні, істотним ускладненням і подорожчанням технологій та випереджальним зростанням необхідної інфраструктури при освоєнні все важкодоступніших енергоресурсів. Науково-технічний прогрес, який значно нівелював у XX ст. негативну дію фактора виснаження обмежених ресурсів, у XXI ст. явно не справляється з цим завданням. Для забезпечення необхідної пропозиції енергії потрібні величезні інвестиції в енергетику, які, за оцінками Міжнародного енергетичного агентства [1], 
мають скласти до 2030 р. 17 трлн дол., при цьому дві третини їх підуть на заміщення існуючих потужностей і одна третина - на створення нових. Але енергобезпека - це так звана екстерналія: суспільне благо, яким всі хочуть користуватися, але ніхто не хоче оплачувати. Для забезпечення безпеки потрібні резерви добувних і інфраструктурних потужностей, тобто системна надмірність. Проте кожний інвестор знає, що основну частину часу ці потужності не завантажені і, отже, не окупатимуться. Очевидно, що в такій ситуації ринкових стимулів для інвестицій немає, що збільшує інвестиційний дефіцит у галузі. Наростання енергоспоживання на фоні повільного зростання пропозиції вже виявляється у стрибку цін на всі комерційні види палива. Зростаючі і, що особливо небезпечно для інвесторів, нестійкі ціни на енергоносії є загрозою для світової економіки і кожної країни окремо. При збереженні напруженості енергопостачання темпи зростання світового ВВП можуть знизитися 3 недавно прогнозованих 3,6-4\% до 3-3,2\% і менше. Найбільші труднощі виникнуть у тих країн-імпортерів енергоносіїв, де низький рівень доходу, що загрожує політичними потрясіннями.

У дослідженні Міжнародного енергетичного агентства «World Energy Outlook 2014» зазначається, світовий попит на енергію зростатиме, однак темпи зростання сповільнюватимуться. Світовий попит на енергію зросте на $37 \%$ до 2040 року. Експерти МЕА зазначають, що, починаючи з 2025 року, попит на енергію зростатиме всього на $1 \%$ щороку порівняно з більш ніж $2 \%$ на рік сьогодні. Близько $60 \%$ світового зростання попиту на енергію припаде на Азію, далі 5 найбільш активними споживачами енергії будуть Африка, Близький Схід і Латинська Америка. Що стосується Китаю, то на початку 2030-х років він стане найбільшим споживачем нафти та газу у світі. У країнах ОЕСР, незважаючи на стабільний економічний розвиток, попит на енергоресурси збільшиться незначно, що пояснюється прийнятими за останні роки заходами щодо підвищення енергоефективності та відповідного зниження питомого енергоспоживання на виробництво продукції. Для країн-членів ОЕСР «блакитне паливо» залишатиметься основним видом палива в енергобалансі включно до 2030 року. Відзначено, що видобуток природного газу зросте майже у всіх регіонах, у тому числі в США та в Європі за рахунок видобутку нетрадиційного газу та нафти. Відмічено також зростання обсягів СПГ як одного з напрямів захисту від перебоїв 3 постачання природного газу. Що стосується попиту на вугілля, то він зростатиме до 15\% від сьогоднішнього рівня і дві третини цього приросту буде забезпечено протягом найближчих десяти років. До 2040 року глобальні поставки енергії, як очікується, складатимуться з чотирьох приблизно однакових частин: низьковуглецевих (ядерних і ПДЕ), нафти, природного газу і вугілля [9; 10].

Тому і надалі найважливішим питанням залишається зменшення показників первинного енергоспоживання у світі. Показовим є останнє двадцятиріччя, зокрема від 2000 р. по 2019 р.

Зважаючи на вищевказані показники, слід зазначити, що найбільш стабільною є Свропа. Динаміка первинного енергоспоживання в Європі протягом 2000-2019 років (рис. 1) та темпи його приросту (табл. 2) засвідчують абсолютні та відносні зміни, що відбулися. За 2000 р. первинне енергоспоживання за даним регіоном світу становило 87,47ТВт-год, а за 2019 р. - 83,82ТВт-год (табл. 1). Порівнюючи значення за перший і останній 3 досліджуваних 20 років, слід відмітити, що відбулося зменшення показника на 3,65ТВт-год або на 4,17\% по відношенню до показника за 2000 рік.

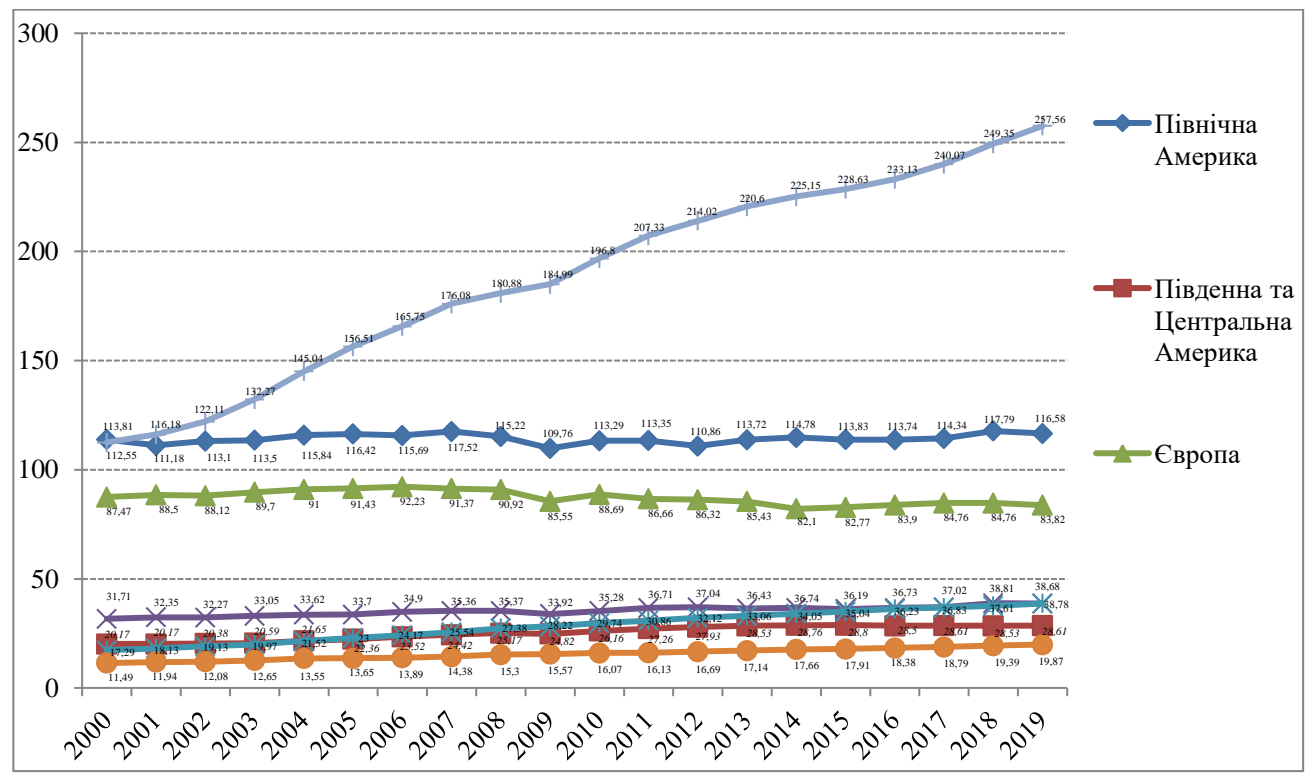

Рис. 1. Динаміка первинного енергоспоживанняв світі протягом 2000-2019 років, ТВт-год (терават-година) 
崖

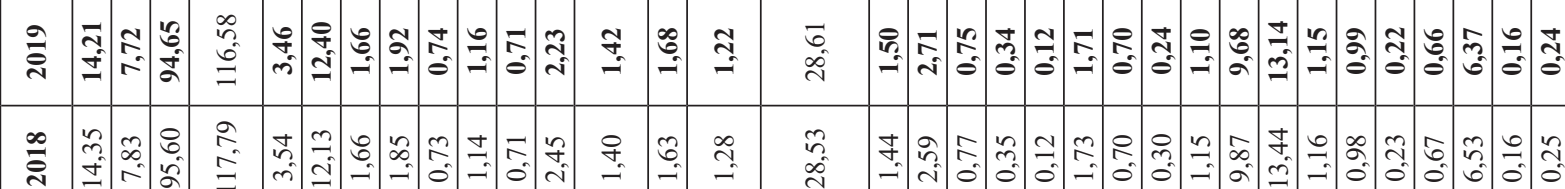

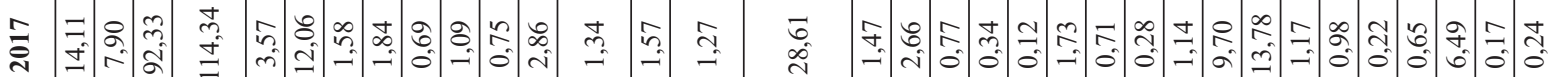

0 a g j

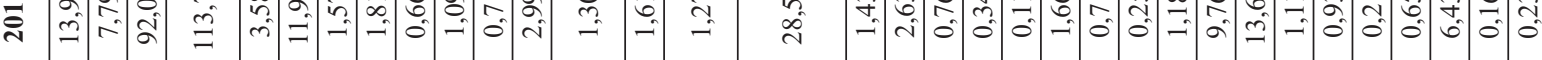

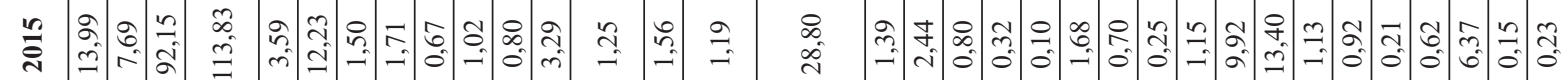

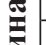

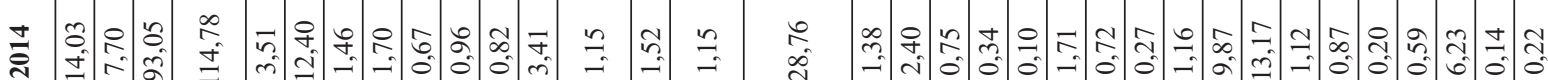

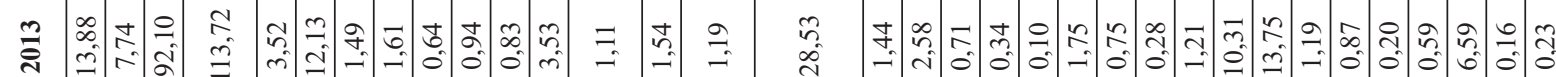

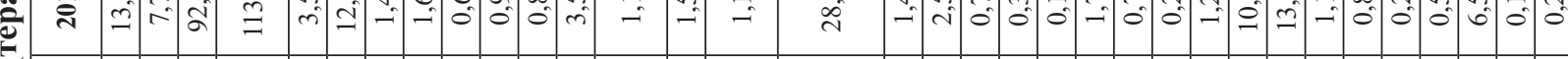

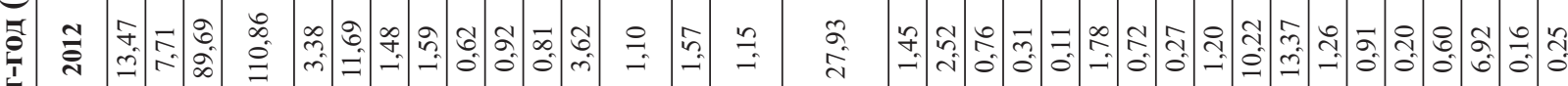

要

పై

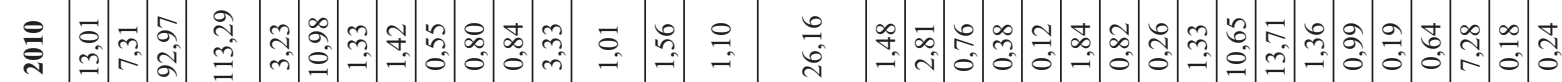

궁

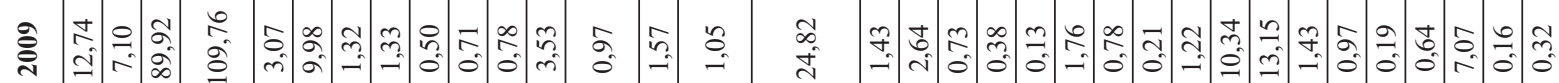

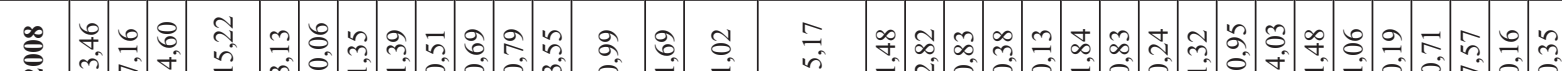

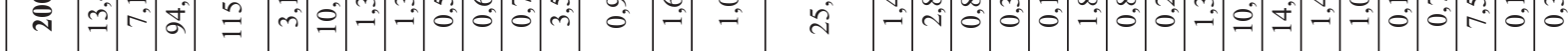

ปิ่

究

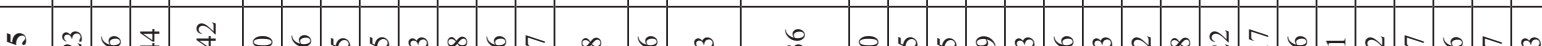

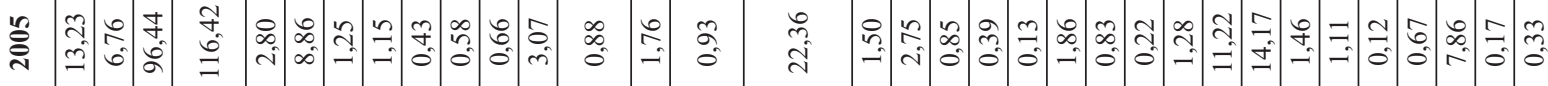

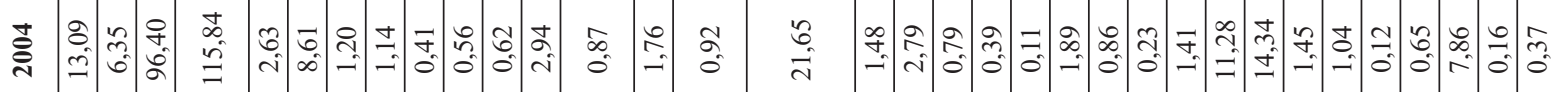

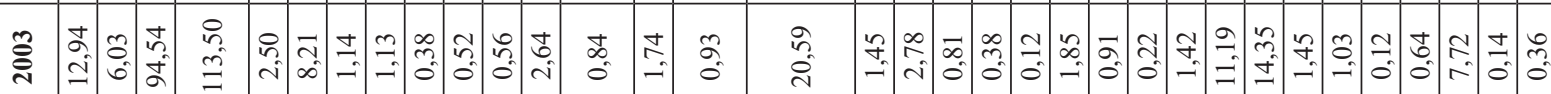

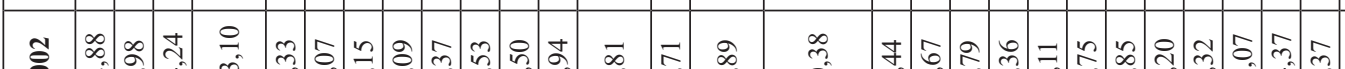

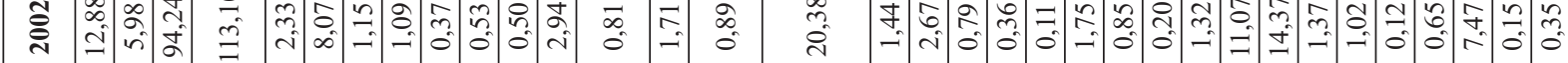

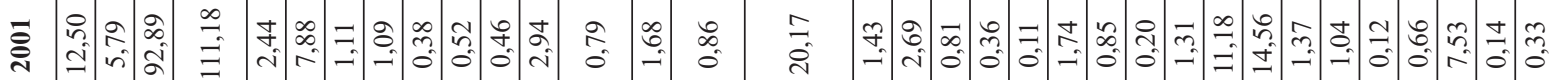

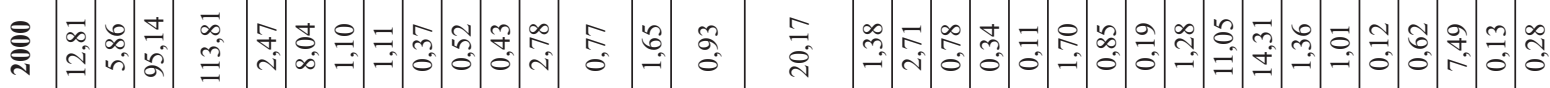

至 


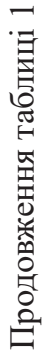

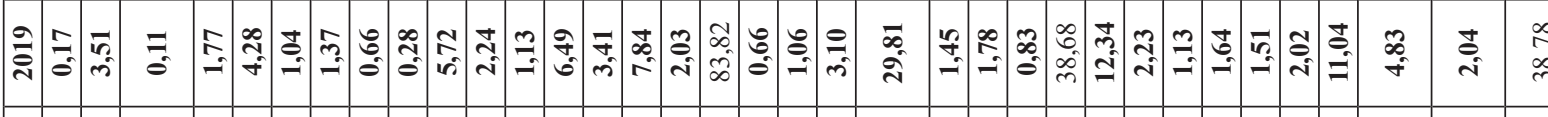

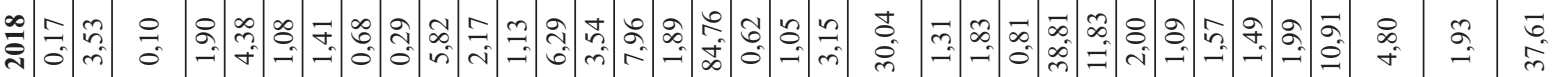

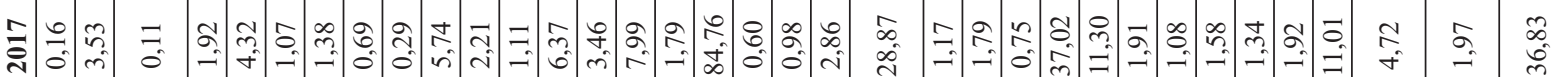

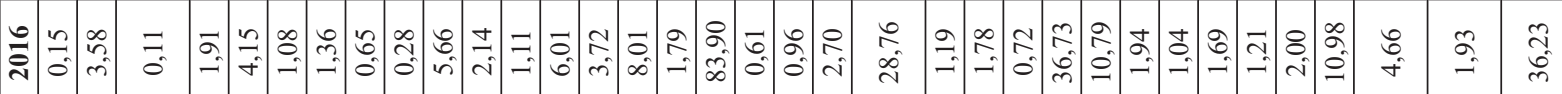

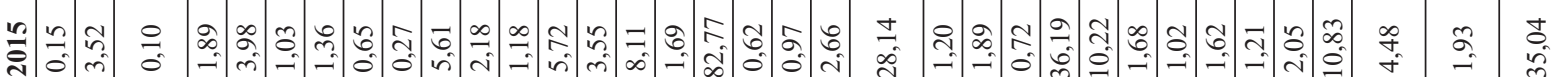

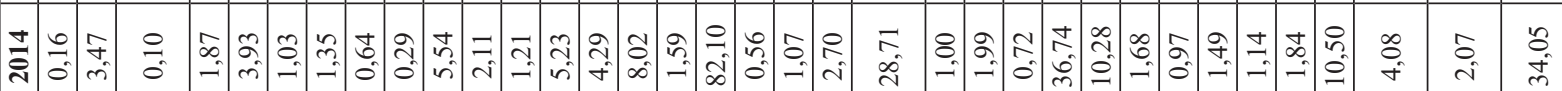

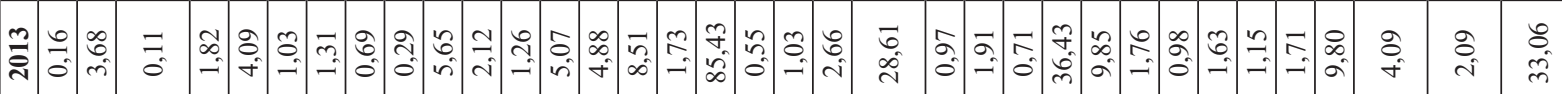

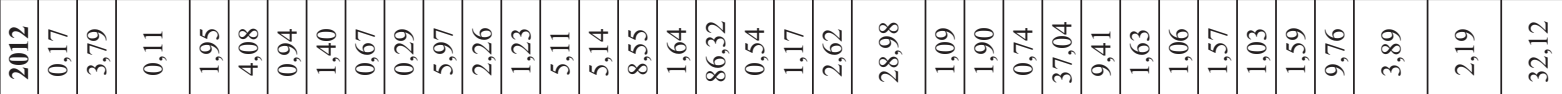

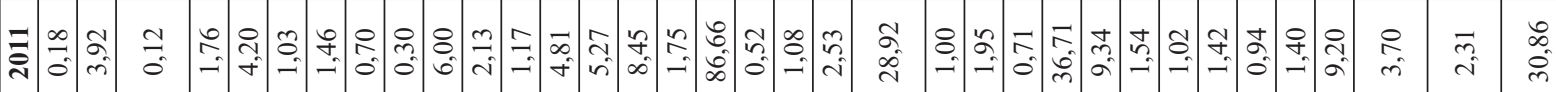

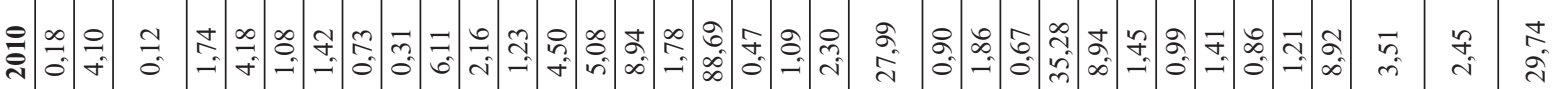

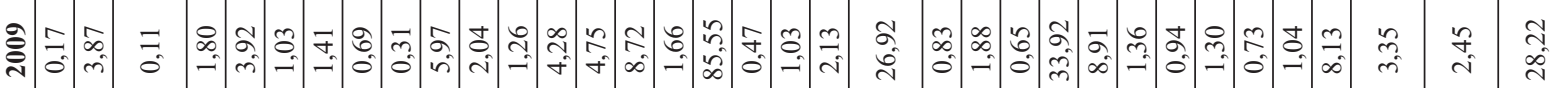

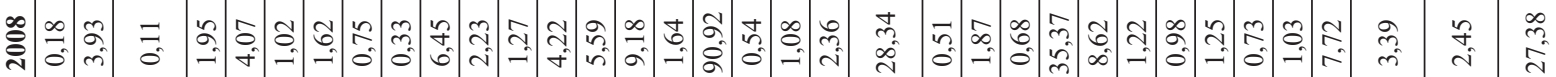

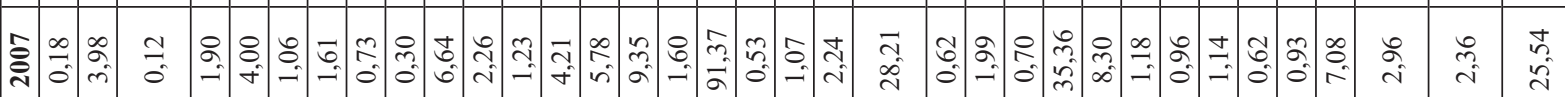

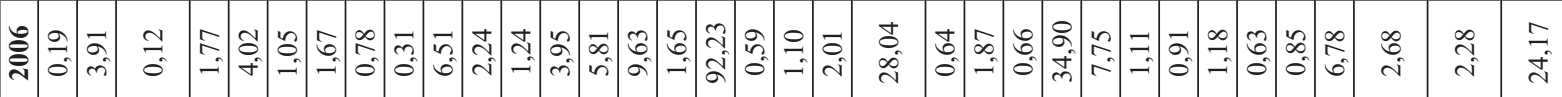
ڤై

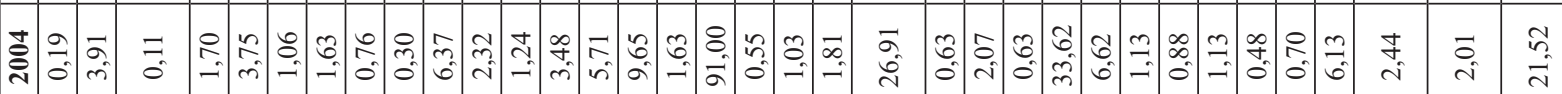

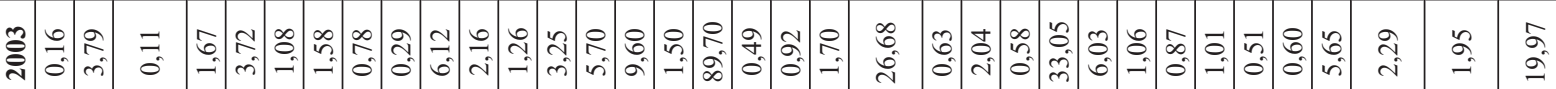

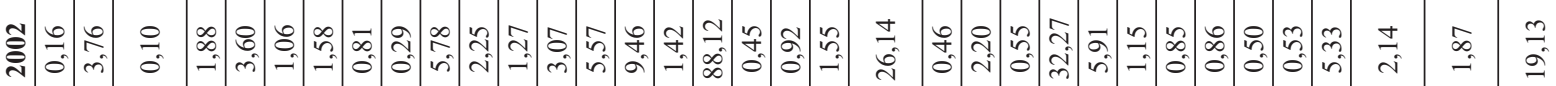

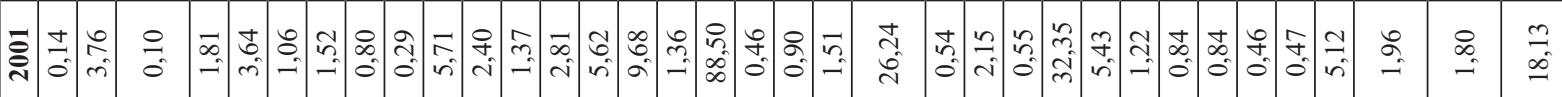

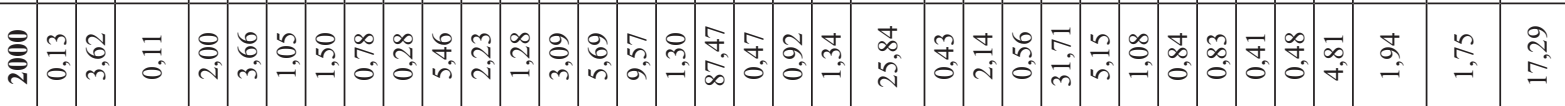

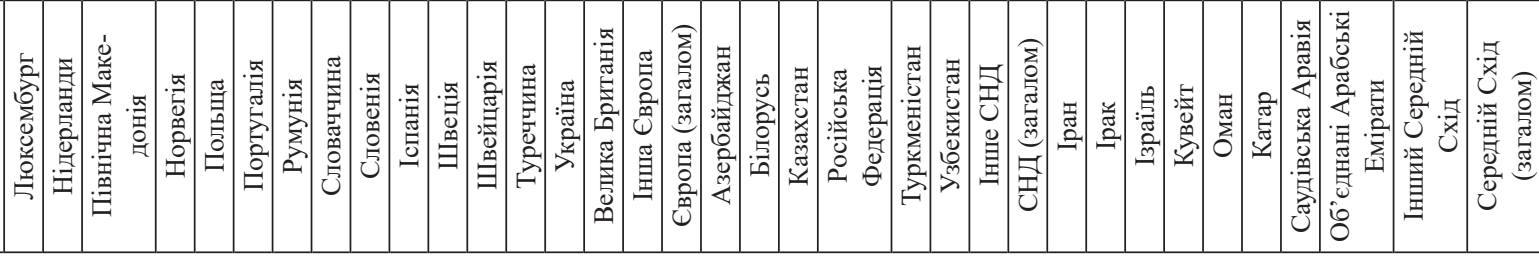


焉

\begin{tabular}{|c|c|c|c|c|c|c|c|c|c|c|c|c|c|c|c|c|c|c|c|c|c|c|c|c|c|c|c|}
\hline & & & & & 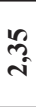 & $\bar{\sigma}$ & & $\Xi$ & & $\begin{array}{l}\infty \\
\infty \\
\Omega\end{array}$ & $F_{\delta}^{F}$ & $=$ & 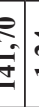 & $\stackrel{\Delta}{=}$ & {$\left[\begin{array}{l}\sigma_{0}^{\circ} \\
\infty\end{array}\right.$} & $\mid \begin{array}{c}5 \\
\infty \\
\infty\end{array}$ & 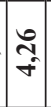 & $\begin{array}{l}\tilde{\sigma} \\
\hat{\sigma}\end{array}$ & ชి & 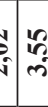 & $\hat{\mathfrak{z}}$ & 足. & $\begin{array}{l}\bar{\infty} \\
+ \\
+\end{array}$ & $\begin{array}{l}\bar{b} \\
\text { is }\end{array}$ & $\underset{f}{\approx}$ & స్ & $\begin{array}{l}\stackrel{0}{n} \\
\tilde{n}\end{array}$ \\
\hline & $\mathcal{F}_{n}$ & S. & $\begin{array}{l}\infty \\
\infty \\
0\end{array}$ & లి & ָ̃ & ڤ. & in & o. & & ले & $\begin{array}{l}8 \\
0 \\
0\end{array}$ & 我 & $\begin{array}{l}\text { E } \\
\tilde{m}\end{array}$ & 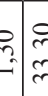 & $\hat{n}$ & $\begin{array}{l}\infty \\
\infty \\
\infty \\
\infty\end{array}$ & $\begin{array}{l}\vec{\sim} \\
\stackrel{\nabla}{*}\end{array}$ & 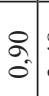 & $\stackrel{\infty}{\text { m. }}$ & $=\begin{array}{l}\vec{b} \\
=\end{array}$ & $\begin{array}{l}n \\
n \\
\simeq \\
\simeq\end{array}$ & $\mid \begin{array}{c}n \\
\tilde{0} \\
0\end{array}$ & $\begin{array}{l}\tilde{\gamma} \\
\sigma_{f}\end{array}$ & $\begin{array}{l}8 \\
\text { in }\end{array}$ & $\begin{array}{l}N \\
m\end{array}$ & $\frac{\Delta}{m}$ & $\begin{array}{l}n \\
\tilde{n} \\
\stackrel{+}{d}\end{array}$ \\
\hline & 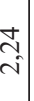 & $\begin{array}{l}+ \\
\infty \\
\infty\end{array}$ & $\begin{array}{c}+ \\
\infty \\
0\end{array}$ & $\begin{array}{l}\text { ते } \\
\text { ñ }\end{array}$ & $\frac{n}{i}$ & $\begin{array}{l}\infty \\
\infty \\
0\end{array}$ & ले & $\hat{o}$ & & $\begin{array}{l}2 \\
\infty \\
\infty\end{array}$ & $\begin{array}{l}\infty \\
0 \\
n\end{array}$ & ले. & $\begin{array}{l}0 \\
0 \\
0 \\
0 \\
0\end{array}$ & $\stackrel{\vec{c}}{-\vec{m}}$ & $\hat{n}$ & $\begin{array}{l}2 \\
\infty \\
\infty \\
\infty\end{array}$ & 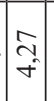 & $\vec{\sigma}$ & 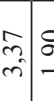 & 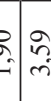 & {$\left[\begin{array}{l}\tilde{n} \\
\mathfrak{c}\end{array}\right.$} & $\begin{array}{c}m \\
\tilde{0} \\
\vdots\end{array}$ & $\begin{array}{c}\infty \\
+ \\
+\end{array}$ & $\begin{array}{l}\text { if } \\
\text { in }\end{array}$ & 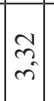 & $\begin{array}{l}0 \\
i \\
i\end{array}$ & $\stackrel{+}{\sim}$ \\
\hline & $\begin{array}{l}\text { ה } \\
\text { ה }\end{array}$ & 过 & $\begin{array}{l}8 \\
\infty \\
0 \\
0\end{array}$ & $\begin{array}{l}\text { m. } \\
\text { in }\end{array}$ & $\underset{i}{ \pm}$ & $\bar{\sigma}$ & त̂ & $\hat{o}$ & 0 & $\begin{array}{l}\infty \\
m^{\infty} \\
\infty\end{array}$ & $\begin{array}{l}\infty \\
\infty \\
i \\
\text { n. }\end{array}$ & $\stackrel{+}{m}$ & ֵَ & $\begin{array}{c}\vec{v} \\
- \\
\end{array}$ & 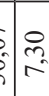 & $\begin{array}{l}2 \\
0 \\
0 \\
0\end{array}$ & $\begin{array}{l}\vec{\jmath} \\
\tilde{f}\end{array}$ & $\begin{array}{c}2 \\
\infty \\
0\end{array}$ & $\stackrel{\vec{m}}{\stackrel{2}{m}}$ & 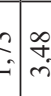 & $\mid \begin{array}{l}0 \\
i \\
c\end{array}$ & $\begin{array}{c}\vec{m} \\
\tilde{0}\end{array}$ & $\begin{array}{l}n \\
\infty \\
+\end{array}$ & $\begin{array}{l}0 \\
\text { n. } \\
\text { in }\end{array}$ & $\begin{array}{l}\exists \\
m^{\prime}\end{array}$ & $\underset{i}{+}$ & $\overrightarrow{\widetilde{\lambda}}$ \\
\hline & & & & & $\stackrel{i}{i}$ & $\begin{array}{l}2 \\
\infty \\
0 \\
0\end{array}$ & $\frac{n}{i}$ & 8 & $\begin{array}{l}\text { ते } \\
\text { o }\end{array}$ & ন & $\begin{array}{c}5 \\
\infty \\
\text { in }\end{array} \mid$ & $\stackrel{2}{=}$ & & & $\overrightarrow{0}$ & $\mid \begin{array}{l}\hat{\alpha} \\
\infty\end{array}$ & $\mid$\begin{tabular}{c}
8 \\
\hdashline \\
+
\end{tabular} & $\begin{array}{l}\partial_{0} \\
\partial^{\prime}\end{array}$ & 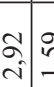 & $=\stackrel{c}{c}=\stackrel{m}{m}$ & $\hat{\infty}$ & $\begin{array}{l}\stackrel{2}{2} \\
0\end{array}$ & $\begin{array}{l}\hat{R} \\
\dot{f}\end{array}$ & ñ & $\begin{array}{l}2 \\
\text { i }\end{array}$ & $\begin{array}{l}\tilde{a} \\
\text { an }\end{array}$ & \\
\hline
\end{tabular}

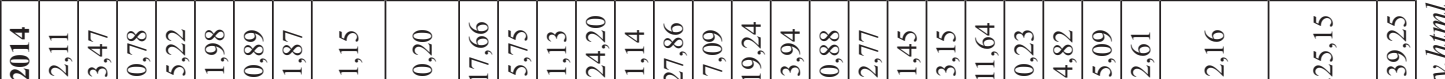

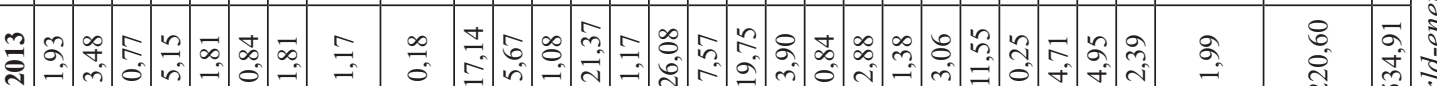

(l)

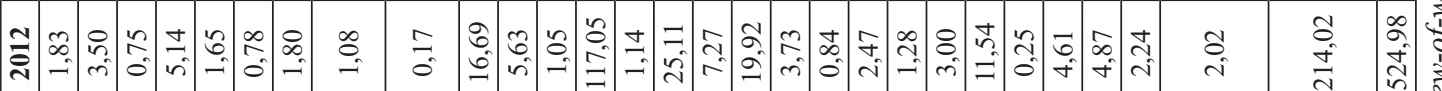

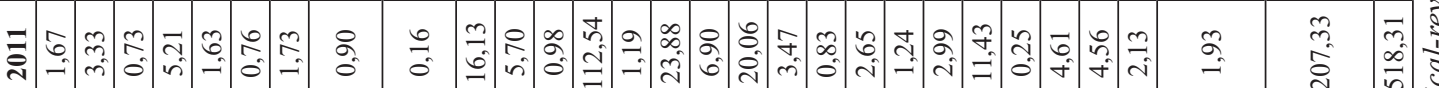

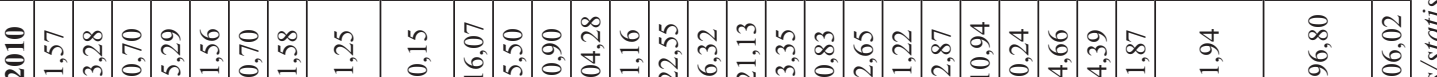

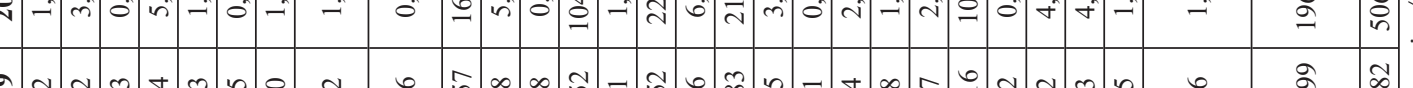

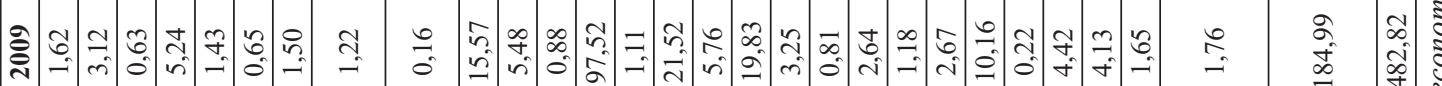

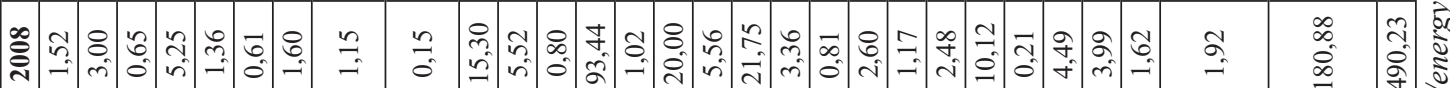

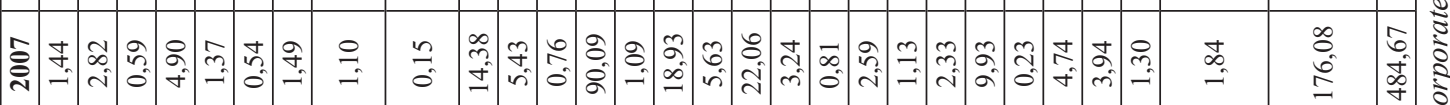

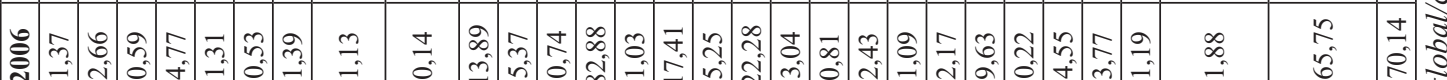

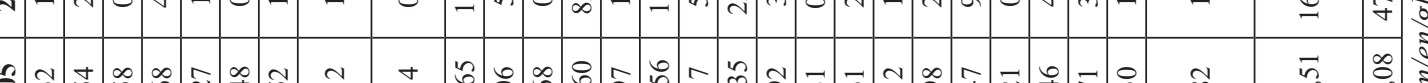

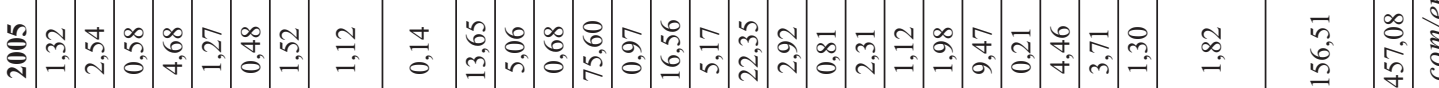

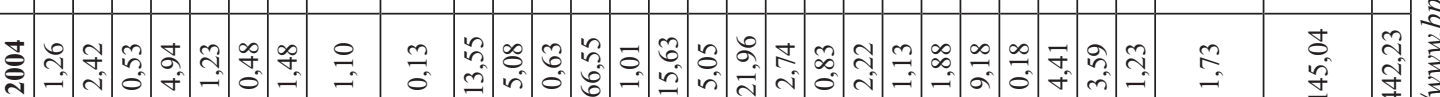

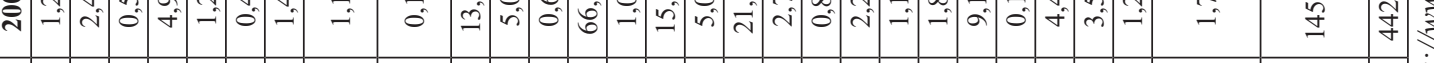

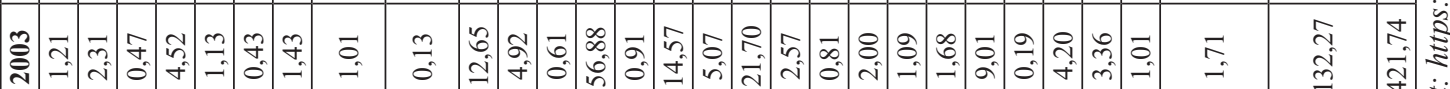

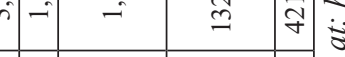

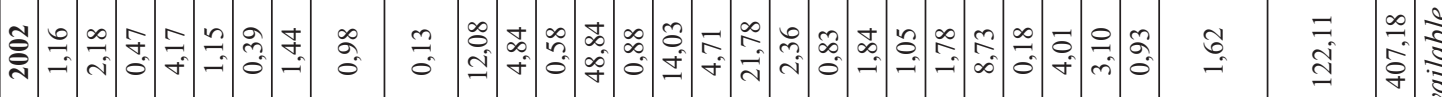

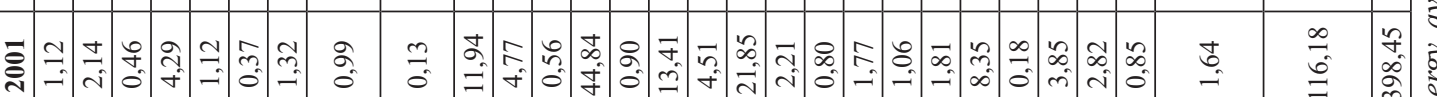

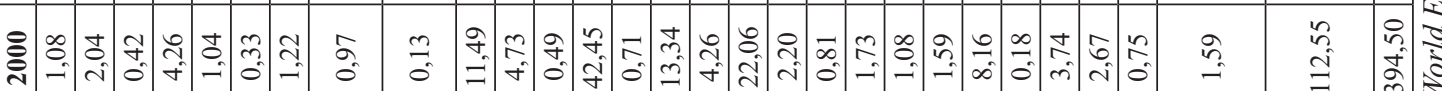

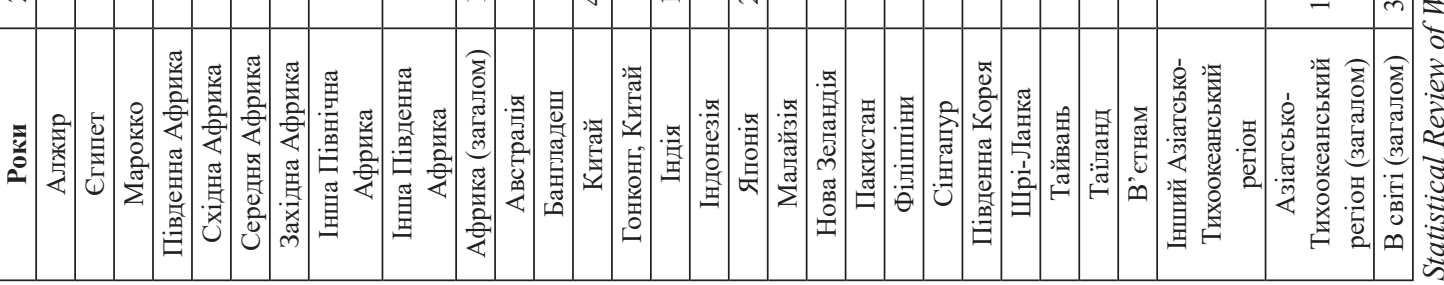


믈

\begin{tabular}{|c|c|c|c|c|c|c|c|c|c|c|c|c|c|c|c|c|c|c|c|c|c|c|c|c|c|c|c|c|c|c|c|}
\hline डેे & $\begin{array}{l}8 \\
\vdots \\
2 \\
2\end{array}$ & & $\begin{array}{l}8 \\
8 \\
8\end{array}$ & $\begin{array}{l}\infty \\
\infty \\
\infty \\
\infty\end{array}$ & $\begin{array}{l}2 \\
\hat{2} \\
\hat{2}\end{array}$ & & a. & 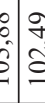 & & & & $\begin{array}{l}\stackrel{n}{n} \\
\stackrel{0}{0}\end{array}$ & $\left|\begin{array}{l}\infty \\
\hat{i} \\
0\end{array}\right|$ & $\begin{array}{l}\text { m. } \\
\text { s. }\end{array}$ & $\begin{array}{l}\text { ते } \\
\stackrel{\text { gै }}{=}\end{array}$ & $\begin{array}{c}m \\
\stackrel{2}{0} \\
\stackrel{0}{0}\end{array}$ & $\begin{array}{l}2 \\
\dot{0} \\
0 \\
-\end{array}$ & & & & & & & & & 0 & & & 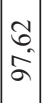 & & $\begin{array}{l}n \\
2 \\
2\end{array}$ \\
\hline$\stackrel{\infty}{\stackrel{\infty}{\sim}}$ & $\begin{array}{l}2 \\
0 \\
0 \\
0\end{array}$ & & & $\begin{array}{l}\tilde{\delta} \\
\tilde{\delta} \\
\hat{\varrho}\end{array}$ & $\begin{array}{l}\hat{\lambda} \\
2\end{array}$ & & $\begin{array}{c}c \\
\vdots \\
0\end{array}$ & 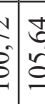 & $\begin{array}{l}\mathscr{\sigma} \\
\stackrel{d}{0}\end{array}$ & & & 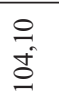 & \begin{tabular}{|l|}
2 \\
$\hat{0}$ \\
0
\end{tabular} & $\begin{array}{l}\text { bे } \\
\stackrel{0}{0}\end{array}$ & $\begin{array}{l}R \\
\stackrel{2}{a}\end{array}$ & 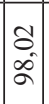 & $\begin{array}{l}\overrightarrow{7} \\
\vdots \\
\vdots \\
0\end{array}$ & & & & & & & & & & & & $\mid \begin{array}{l}1 \\
0 \\
0 \\
\vdots \\
0\end{array}$ & & $\mid \begin{array}{l}9 \\
9 \\
8 \\
8\end{array}$ \\
\hline 亏ે & 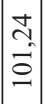 & & & $\begin{array}{l}\tilde{n} \\
\hat{2} \\
8 \\
0\end{array}$ & $\begin{array}{l}\Delta \\
\dot{2} \\
2\end{array}$ & & $\begin{array}{l}2 \\
8 \\
8 \\
0\end{array}$ & $=\hat{l}=0$ & 今. & & $\vec{n}$ & 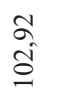 & $\begin{array}{l}₫ \\
\vdots \\
\vdots \\
\vdots\end{array}$ & 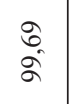 & $\begin{array}{l}\stackrel{9}{9} \\
\stackrel{1}{0}\end{array}$ & 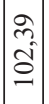 & $\begin{array}{l}n \\
- \\
- \\
-1\end{array}$ & & 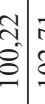 & $\stackrel{\infty}{a}$ & 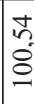 & - & & & & & $=$ & & $\left|\begin{array}{l}\alpha \\
\delta \\
\delta \\
0\end{array}\right|$ & & $\begin{array}{l}5 \\
0 \\
0 \\
0 \\
0\end{array}$ \\
\hline ัํำ & బे & & & $\begin{array}{l}\tilde{\alpha} \\
\text { aे }\end{array}$ & $\left|\begin{array}{c}\hat{2} \\
\tilde{\alpha}\end{array}\right|$ & & 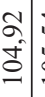 & 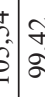 & 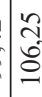 & $\mathrm{N}$ & ¿ & $\begin{array}{l}\text { I } \\
\text { \& } \\
\text { a }\end{array}$ & 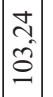 & $\stackrel{\infty}{\stackrel{\infty}{0}}$ & $\begin{array}{l}\text { ڤ̊ } \\
\text { ळे }\end{array}$ & $\mid \begin{array}{l}\vec{m} \\
\hat{0} \\
0\end{array}$ & 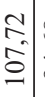 & & 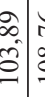 & 7 & $\infty$ & 6 & 8 & m & 0 & 7 & $\subseteq$ & & $\mid$ & & $\begin{array}{l}\mathbb{N} \\
0 \\
0\end{array}$ \\
\hline 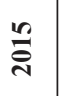 & $\begin{array}{c}\Re \\
2 \\
\alpha\end{array}$ & & & $\vec{a}$ & $\left|\begin{array}{l}n \\
0 \\
0 \\
0\end{array}\right|$ & & & $\begin{array}{c}c \\
\vdots \\
2\end{array}$ & 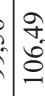 & $\hat{\imath}$ & $\begin{array}{l}\infty \\
\text { sed } \\
\text { s. }\end{array}$ & $\begin{array}{l}\tilde{\alpha} \\
\text { के }\end{array}$ & $\left|\begin{array}{l}0 \\
0 \\
\mathbf{d} \\
0\end{array}\right|$ & 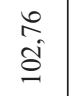 & $\frac{ \pm}{\stackrel{\Xi}{g}}$ & $\begin{array}{l}0 \\
\stackrel{0}{\circ} \\
\stackrel{0}{0}\end{array}$ & $\begin{array}{c}\underset{J}{+} \\
\stackrel{-}{0}\end{array}$ & $f$ & 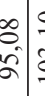 & 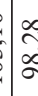 & 17 & $\begin{array}{c}\infty \\
0\end{array}$ & & in & $F$ & 8 & 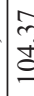 & & $\mid \begin{array}{l}\overrightarrow{\hat{y}} \\
\hat{\Xi} \\
0\end{array}$ & & $\stackrel{+}{\stackrel{0}{0}}$ \\
\hline & $\mid \begin{array}{l}\infty \\
0 \\
0 \\
0 \\
0\end{array}$ & & & $\begin{array}{l}t \\
8 \\
8 \\
0\end{array}$ & $\left|\begin{array}{l}0 \\
2 \\
2\end{array}\right|$ & & & & $\begin{array}{l}\text { I. } \\
\text { d. }\end{array}$ & q & $\begin{array}{l}\text { to } \\
\text { की }\end{array}$ & 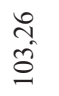 & $\left|\begin{array}{c}2 \\
2 \\
\alpha \\
\alpha\end{array}\right|$ & 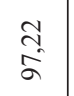 & $\begin{array}{l}\stackrel{\hat{\theta}}{8} \\
\stackrel{8}{0}\end{array}$ & $\begin{array}{c} \pm \\
\vdots \\
\vdots \\
2\end{array}$ & $\begin{array}{c}\infty \\
\text { âd }\end{array}$ & $\begin{array}{l}y \\
y\end{array}$ & $\begin{array}{l}b_{0} \\
\sigma_{0}^{2}\end{array}$ & 7 & ठ. & it & $\approx$ & $\begin{array}{c}\hat{2} \\
\text { â }\end{array}$ & $\infty$ & c & \& & & $\mid \begin{array}{l}a \\
\dot{f} \\
\dot{d}\end{array}$ & & $0^{\circ}$ \\
\hline 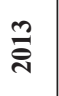 & $\begin{array}{l}\hat{0} \\
\hat{0} \\
0\end{array}$ & & & $\begin{array}{l}\tilde{n} \\
\tilde{s} \\
\underline{n}\end{array}$ & $\begin{array}{l}2 \\
\overrightarrow{0} \\
0\end{array}$ & & & 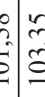 & $\begin{array}{l}2 \\
\text { iे } \\
\text { s. }\end{array}$ & $\infty$ & 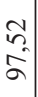 & $\begin{array}{l}\hat{\infty} \\
\hat{8} \\
\hat{\theta}\end{array}$ & 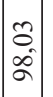 & 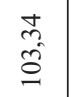 & & $\left|\begin{array}{c}n \\
2 \\
2 \\
2\end{array}\right|$ & $\begin{array}{c}n \\
\vdots \\
\hat{s} \\
0\end{array}$ & & $\begin{array}{l}8 \\
\vdots \\
\vdots \\
\vdots\end{array}$ & 2 & $\stackrel{f}{9}$ & of & \pm & $\infty$ & $\tilde{\infty}^{-1}$ & $\varepsilon$ & $\varrho$ & & 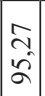 & & สू \\
\hline હิ & $\begin{array}{l}8 \\
\vdots \\
8\end{array}$ & $\begin{array}{l}\hat{n} \\
\vdots \\
\vdots\end{array}$ & & 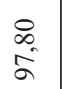 & $\mid$ & $\begin{array}{l}\hat{2} \\
\overrightarrow{0} \\
0\end{array}$ & 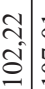 & 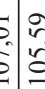 & 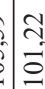 & g & $\begin{array}{l}\stackrel{ }{\circ} \\
\stackrel{+}{0}\end{array}$ & $\begin{array}{l}\text { ñ } \\
\text { }\end{array}$ & $\begin{array}{c}n \\
\hat{2} \\
2\end{array}$ & $\begin{array}{l}\stackrel{\infty}{+} \\
\stackrel{s}{\subseteq}\end{array}$ & $\begin{array}{l}\text { an } \\
\text { s. } \\
\end{array}$ & $\begin{array}{l}\text { o. } \\
\dot{0} \\
\stackrel{d}{0}\end{array}$ & $\begin{array}{c}\frac{1}{6} \\
\sigma^{\circ}\end{array}$ & $\delta$ & : & i & 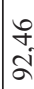 & $\begin{array}{r}\stackrel{n}{0} \\
=\end{array}$ & $\bar{\infty}$ & 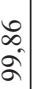 & ivi & 2 & 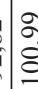 & & & & 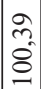 \\
\hline Еั & $\begin{array}{l}8 \\
0 \\
0 \\
0\end{array}$ & $\begin{array}{c}\infty \\
\vdots \\
\vdots \\
0\end{array}$ & & $\begin{array}{l}8 \\
\stackrel{0}{0} \\
\stackrel{0}{0}\end{array}$ & $\mid \begin{array}{l}\Omega \\
\hat{0} \\
0\end{array}$ & & $\begin{array}{l}\hat{N} \\
8 \\
0 \\
0\end{array}$ & 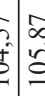 & 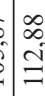 & $\vec{\sim}$ & 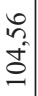 & $\begin{array}{l}\stackrel{0}{\hat{n}} \\
\varrho\end{array}$ & $\begin{array}{l}\stackrel{2}{1} \\
\stackrel{0}{0}\end{array}$ & 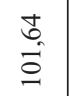 & $\begin{array}{l}\text { Ĩ } \\
\dot{\Xi} \\
\stackrel{0}{*}\end{array}$ & $\left|\begin{array}{c}0 \\
\vdots \\
0 \\
2\end{array}\right|$ & $\begin{array}{c}\overrightarrow{3} \\
\sigma^{2}\end{array}$ & 2 & $\begin{array}{l}\infty \\
\vdots \\
\vdots \\
\infty \\
\infty\end{array}$ & $\bar{\infty}^{\infty}$ & m & 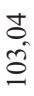 & 8 & $m$ & 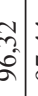 & 9 & 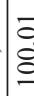 & & $\mid \begin{array}{l}\infty \\
\vdots \\
\vdots \\
a\end{array}$ & & $\stackrel{\varrho}{\varrho}$ \\
\hline હે & $\mid \begin{array}{l}m \\
i \\
\hat{d} \\
0\end{array}$ & 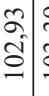 & & $\begin{array}{l}\overrightarrow{\vec{a}} \\
\hat{\tilde{\theta}}\end{array}$ & $\left|\begin{array}{c}\hat{\lambda} \\
\hat{0} \\
0\end{array}\right|$ & & & 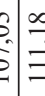 & $\begin{array}{l}\infty \\
0 \\
\mathcal{I}\end{array}$ & $\begin{array}{l}t \\
\infty\end{array}$ & $\begin{array}{l}\text { ते } \\
\text { से }\end{array}$ & 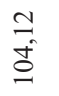 & 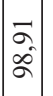 & $\begin{array}{l}\hat{b} \\
\mathbb{0} \\
0\end{array}$ & $\begin{array}{l}\vec{F} \\
\tilde{b}\end{array}$ & $\begin{array}{l}\text { ले } \\
\stackrel{2}{=}\end{array}$ & 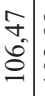 & $=1$ & 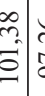 & & $\begin{array}{c}8 \\
\text { in } \\
8\end{array}$ & 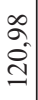 & & है & 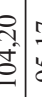 & 8 & $\subseteq$ & & 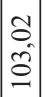 & & $\begin{array}{l}\stackrel{8}{0} \\
\stackrel{+}{1}\end{array}$ \\
\hline క్సે & $\begin{array}{l}8 \\
0 \\
0 \\
0\end{array}$ & 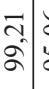 & & $\begin{array}{l}\text { जे } \\
\text { nू. }\end{array}$ & $\left|\begin{array}{c}0 \\
\alpha^{0} \\
\alpha\end{array}\right|$ & $\frac{2}{2}$ & $\begin{array}{l}\hat{2} \\
\hat{\alpha}\end{array}$ & $\begin{array}{l}: \\
\vdots \\
\vdots \\
\vdots\end{array}$ & 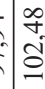 & $\Xi$ & $\begin{array}{l}\tilde{n} \\
2 \\
2\end{array}$ & $\begin{array}{c}\stackrel{7}{\infty} \\
\curvearrowright\end{array}$ & $\begin{array}{l}m \\
\curvearrowright \\
\curvearrowright\end{array}$ & $\begin{array}{l}\hat{\widehat{~}} \\
\text { }\end{array}$ & $\begin{array}{l}\vec{b} \\
\infty^{\circ}\end{array}$ & $\left|\begin{array}{l}1 \\
0 \\
0 \\
\vdots \\
0\end{array}\right|$ & $\begin{array}{c}8 \\
\alpha \\
\alpha\end{array}$ & $\begin{array}{l}0 \\
5 \\
\infty\end{array}$ & 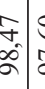 & 10 & 8 & $\begin{array}{c} \pm \\
\infty \\
\infty \\
\infty \\
\infty\end{array}$ & 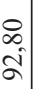 & 9 & $=1$ & $\bar{a}$ & 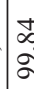 & & $\mid \begin{array}{c}0 \\
2 \\
2 \\
2 \\
\sigma\end{array}$ & & $\begin{array}{l}n \\
\vec{a}\end{array}$ \\
\hline ডે̀ & $\begin{array}{l}\overline{0} \\
8\end{array}$ & $\begin{array}{l}0 \\
\text { s. } \\
\text { s. }\end{array}$ & & $\begin{array}{l} \pm \\
0 \\
\alpha^{\circ}\end{array}$ & $\begin{array}{l}P \\
0 \\
0 \\
0\end{array}$ & $\begin{array}{l}\vec{F} \\
\dot{d} \\
\stackrel{0}{0}\end{array}$ & & $\begin{array}{lll}0 \\
0 \\
0 \\
0\end{array}$ & $\begin{array}{l}\Omega \\
\vdots \\
\vdots\end{array}$ & $n$ & $\stackrel{n}{m}$ & $\begin{array}{l}\stackrel{0}{0} \\
\text { d̂ }\end{array}$ & 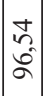 & $\begin{array}{l}\infty \\
\tilde{\delta} \\
\hat{\delta}\end{array}$ & $\begin{array}{l}\tilde{b} \\
\hat{\theta} \\
0\end{array}$ & $\mid \begin{array}{l}\hat{\sigma} \\
\overrightarrow{0} \\
\overrightarrow{0}\end{array}$ & $\begin{array}{l}\mathbb{1} \\
\bar{\Xi} \\
=\end{array}$ & $\begin{array}{l}0 \\
0 \\
0 \\
0 \\
2\end{array}$ & \begin{tabular}{c}
2 \\
\hdashline \\
\hdashline \\
\hdashline
\end{tabular} & 12 & $\begin{array}{l}\text { तె } \\
\text { ूू }\end{array}$ & 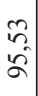 & f & $\stackrel{\infty}{\sim}$ & 8 & $=$ & $\simeq$ & & $\begin{array}{l}\overrightarrow{0} \\
\infty \\
\infty\end{array}$ & 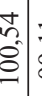 & $=$ \\
\hline ڤ్̀ & 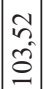 & $\begin{array}{c}1 \\
\vdots \\
\vdots \\
0\end{array}$ & & $\begin{array}{l}\text { के } \\
\text { cे }\end{array}$ & $\mid \begin{array}{c}\vec{F} \\
\dot{d} \\
0\end{array}$ & \begin{tabular}{l}
\multirow{2}{*}{} \\
$\stackrel{2}{0}$
\end{tabular} & & & & $\simeq$ & $\begin{array}{l}8 \\
: \\
8\end{array}$ & $\begin{array}{l}8 \\
\infty \\
\text { +1 }\end{array}$ & 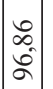 & 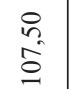 & 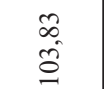 & $\begin{array}{c}0 \\
\vdots \\
\vdots \\
\vdots\end{array}$ & $\begin{array}{l}\vec{b} \\
8 \\
8\end{array}$ & $\begin{array}{l}0 \\
0 \\
0 \\
2\end{array}$ & 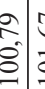 & {$\left[\begin{array}{l}\infty \\
\infty \\
\infty\end{array}\right.$} & \pm & 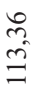 & I & $\Re$ & $F$ & 8 & $=$ & 8 & $\begin{array}{c}m \\
0 \\
0 \\
0\end{array}$ & & $\stackrel{\text { I }}{ }$ \\
\hline ڤ్̀ & $\begin{array}{c}\overrightarrow{1} \\
0 \\
0\end{array}$ & $\begin{array}{l}0 \\
0 \\
0 \\
0\end{array}$ & & $\begin{array}{l}\hat{m} \\
\sigma^{2}\end{array}$ & $\left|\begin{array}{c}0 \\
0 \\
0 \\
0\end{array}\right|$ & $\begin{array}{c}0 \\
\vdots \\
\vdots \\
0\end{array}$ & 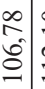 & 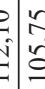 & \begin{tabular}{l}
0 \\
\hdashline \\
0 \\
0
\end{tabular} & $\infty$ & 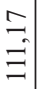 & $\begin{array}{l}\text { s. } \\
\text { ôd }\end{array}$ & $\begin{array}{c}n \\
\tilde{c} \\
\vdots \\
0\end{array}$ & $\begin{array}{l}\hat{\alpha} \\
\hat{\alpha}\end{array}$ & $\stackrel{\infty}{\overrightarrow{0}}$ & 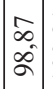 & $\begin{array}{l}\overrightarrow{1} \\
\stackrel{8}{0}\end{array}$ & 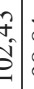 & 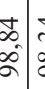 & $\sigma$ & ֶָ & $f$ & 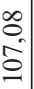 & 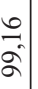 & $\theta$ & is & $=$ & & $\begin{array}{l}n \\
2 \\
2 \\
2\end{array}$ & & $2 \alpha$ \\
\hline ڤ్ & $\mid \begin{array}{l}\tilde{\delta} \\
0 \\
0 \\
0\end{array}$ & \begin{tabular}{l}
7 \\
\multirow{2}{0}{} \\
0 \\
0
\end{tabular} & & 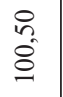 & $\left|\begin{array}{l}6 \\
0 \\
0 \\
0\end{array}\right|$ & $\begin{array}{l}0 \\
0 \\
0 \\
0 \\
0\end{array}$ & డे. & 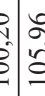 & 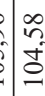 & สี & 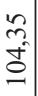 & $\begin{array}{l}\stackrel{8}{0} \\
\stackrel{0}{\Xi}\end{array}$ & 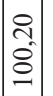 & $\begin{array}{l}\hat{a} \\
\text { ò }\end{array}$ & $\begin{array}{l}\text { ले } \\
\text { હे }\end{array}$ & $\begin{array}{l}\stackrel{2}{1} \\
\overrightarrow{0} \\
0\end{array}$ & $\begin{array}{c}0 \\
\infty \\
\infty \\
\infty \\
\infty\end{array}$ & & 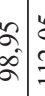 & 1 & $\begin{array}{l}\text { ?f } \\
\text { so } \\
\text { s. }\end{array}$ & 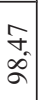 & & $n$ & $a$ & $\tilde{\alpha}$ & 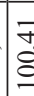 & & & & \\
\hline ঙે & $\begin{array}{l}\overrightarrow{0} \\
\overrightarrow{0}\end{array}$ & $\begin{array}{c}\text { के } \\
\text { है }\end{array}$ & & $\begin{array}{l}8 \\
\text { i } \\
\text { di }\end{array}$ & $\begin{array}{l}2 \\
2 \\
0 \\
0\end{array}$ & $\begin{array}{l}a \\
0 \\
\dot{d} \\
0\end{array}$ & $\begin{array}{l}8 \\
0 \\
0 \\
0\end{array}$ & $\begin{array}{l}0 \\
0 \\
0\end{array}$ & $\begin{array}{l}0 \\
0 \\
0\end{array}$ & aे & 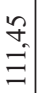 & હે & $\begin{array}{l}\Omega \\
\delta \\
\delta \\
\delta\end{array}$ & $\begin{array}{c}\bar{m} \\
\alpha_{\alpha}^{\circ}\end{array}$ & $\stackrel{\Delta}{\stackrel{\Delta}{\Omega}}$ & $\mid \begin{array}{l}\infty \\
\vdots \\
0 \\
0 \\
0\end{array}$ & 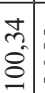 & 6 & 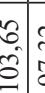 & & f & in & $\infty$ & న & & 7 & 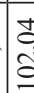 & & $\mid \begin{array}{l}\vec{\infty} \\
\overrightarrow{0} \\
0\end{array}$ & $\begin{array}{c}\infty \\
\underline{3} \\
=\end{array}$ & \\
\hline క్̊ి & 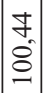 & $\begin{array}{l}0 \\
0 \\
\vdots \\
0\end{array}$ & & $\begin{array}{l}0 \\
0 \\
0 \\
0 \\
0\end{array}$ & $\mid$ & $\begin{array}{l}\hat{a} \\
\overrightarrow{0} \\
0\end{array}$ & $\begin{array}{c}f \\
\sigma^{2}\end{array}$ & $\begin{array}{c}0 \\
0 \\
0\end{array}$ & $\left\{\begin{array}{l}n \\
2 \\
\infty \\
\infty\end{array}\right.$ & 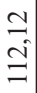 & $a$ & $\begin{array}{l}\vec{n} \\
\overrightarrow{0}\end{array}$ & $\begin{array}{l}a \\
\bar{\Xi} \\
\bar{\Xi}\end{array}$ & $\begin{array}{l}\tilde{0} \\
\dot{0} \\
0\end{array}$ & $\begin{array}{l}\stackrel{r}{0} \\
\stackrel{-}{0}\end{array}$ & 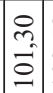 & 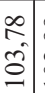 & 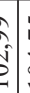 & 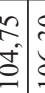 & & $\stackrel{\infty}{\infty}$ & 0 & & ¿ & & 7 & 7 & & & & 0 \\
\hline ڤ్̃ે & $\begin{array}{l}\infty \\
0 \\
0 \\
0 \\
0\end{array}$ & $\begin{array}{c}2 \\
\text { s. } \\
0\end{array}$ & & $\begin{array}{l}\mathbb{2} \\
\vec{a} \\
\vec{a}\end{array}$ & $\mid \begin{array}{l}\vec{z} \\
\approx\end{array}$ & 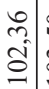 & 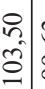 & $\begin{array}{c}6 \\
\vdots \\
\vdots \\
\infty \\
\infty\end{array}$ & : & $\sim$ & 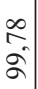 & 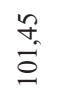 & 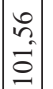 & $\begin{array}{l}\infty \\
m_{0} \\
\hat{\Omega}\end{array}$ & 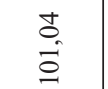 & $\mid$\begin{tabular}{|c}
$\tilde{z}$ \\
$\vdots$ \\
0 \\
0
\end{tabular} & 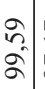 & & : & & $\stackrel{\infty}{\circ}$ & o & & - & & 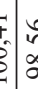 & - & & مి & $\begin{array}{l}\vdots \\
\vdots \\
\bar{\vdots}\end{array}$ & \\
\hline క్ે & $\begin{array}{l}\hat{n} \\
\hat{a} \\
a\end{array}$ & 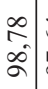 & to & 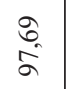 & $\left|\begin{array}{l}2 \\
\infty \\
\infty\end{array}\right|$ & $\begin{array}{c} \pm \\
\infty_{0}^{0}\end{array}$ & $\begin{array}{l}0 \\
\stackrel{0}{0} \\
\vdots \\
0\end{array}$ & 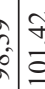 & $=\underbrace{a}_{\infty}$ & & 8 & 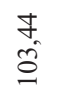 & $\begin{array}{l}\hat{a} \\
\vec{a}\end{array}$ & 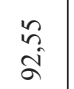 & $\begin{array}{l}\stackrel{2}{\circ} \\
\text { aे }\end{array}$ & 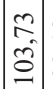 & $\frac{a}{2}$ & & 童 & & $\Delta$ & 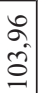 & & $\tau$ & & $t$ & & & $\mid \begin{array}{l}\vec{n} \\
0 \\
0\end{array}$ & $\begin{array}{l}0 \\
0 \\
\vdots \\
0 \\
0\end{array}$ & \\
\hline ڤ్̀ે & $\begin{array}{l}\hat{\jmath} \\
\hat{d} \\
\underline{d}\end{array}$ & 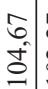 & & 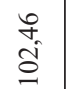 & $\left|\begin{array}{l} \pm \\
0 \\
\dot{0}\end{array}\right|$ & 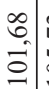 & $\begin{array}{l}\hat{2} \\
\vdots \\
\hat{c}\end{array}$ & 8 & 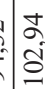 & & $\stackrel{\infty}{\infty}$ & $\begin{array}{l}\underset{+}{+} \\
\text { d }\end{array}$ & $\begin{array}{c}\vec{F} \\
\stackrel{\rho}{\exists}\end{array}$ & $\begin{array}{c}\stackrel{J}{\alpha} \\
\infty\end{array}$ & $\begin{array}{l}\hat{\hat{s}} \\
\hat{\Omega}\end{array}$ & & 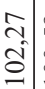 & & 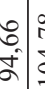 & & C & & & & & & & & & & \\
\hline 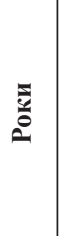 & 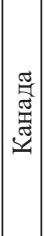 & & & 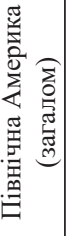 & 递 & & & 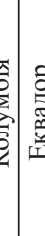 & & & & 党 & & 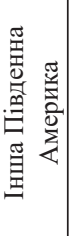 & 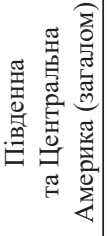 & | & 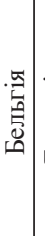 & & 产 & 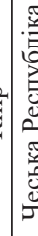 & & 5 & & & & & & & 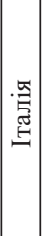 & & \\
\hline
\end{tabular}




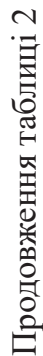

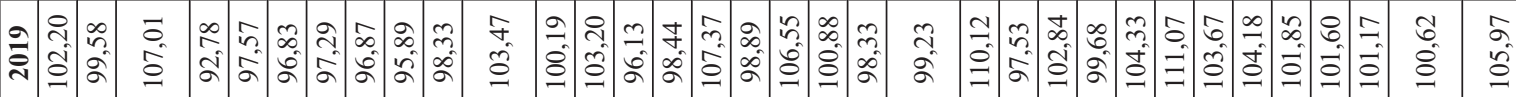

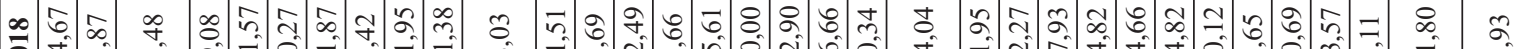

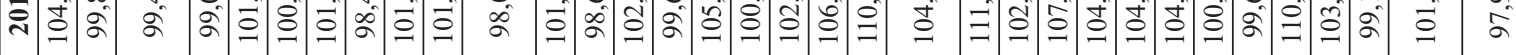
공 సै ఫे

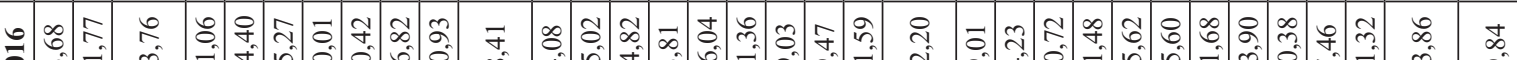

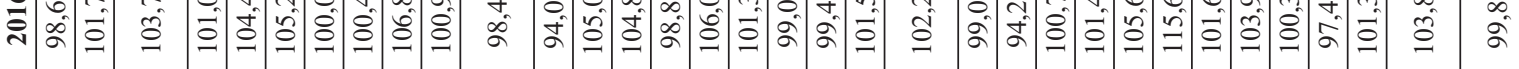
$\because \approx$ ก సें

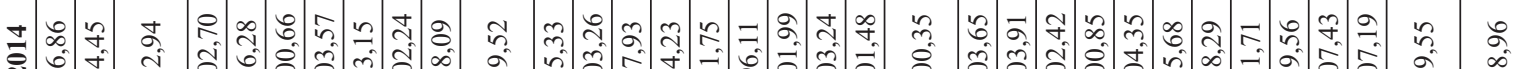

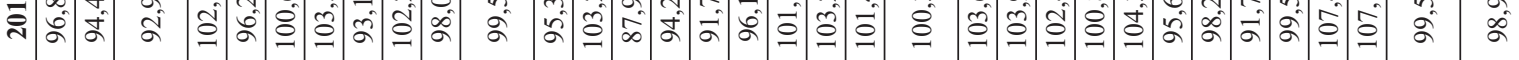
$m$ m

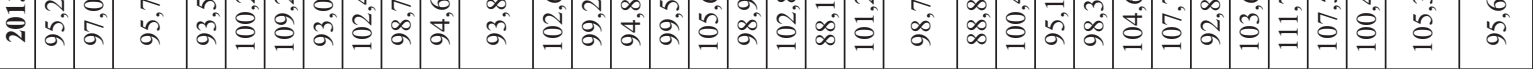

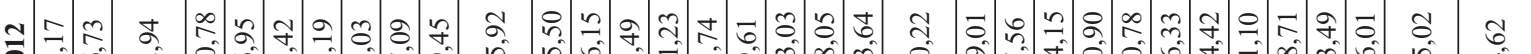

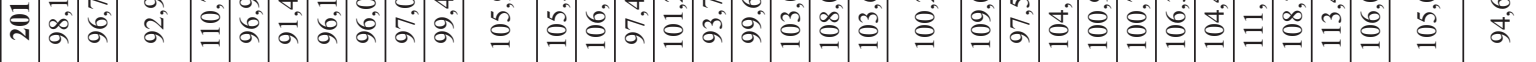

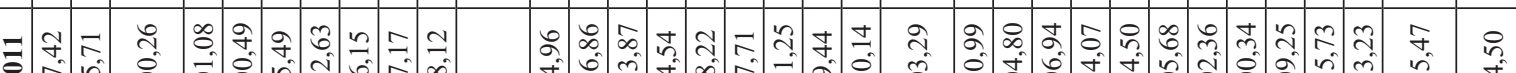
సิे

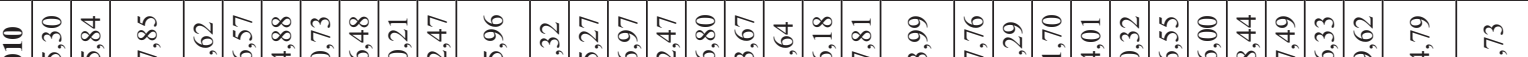
సิ่

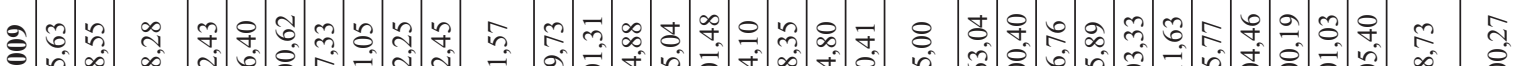

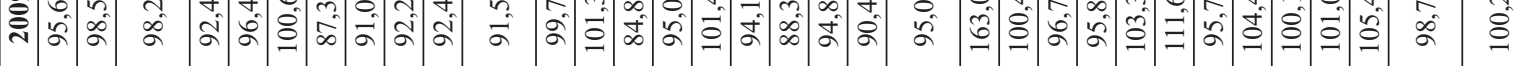
$\infty$ 六 సे

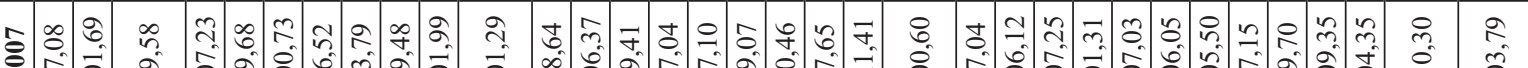
సं

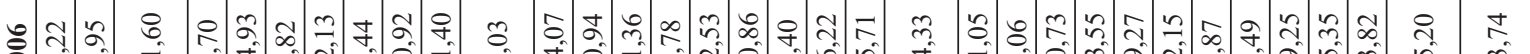

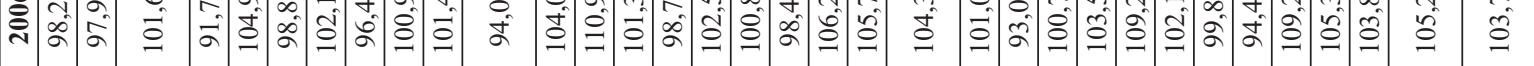

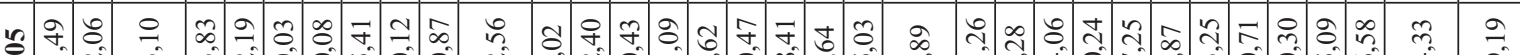
जิ

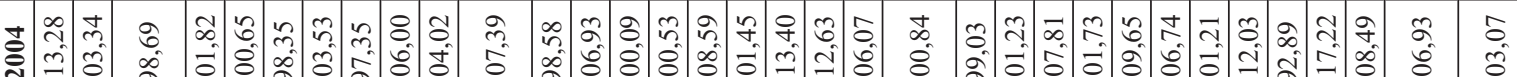
जी

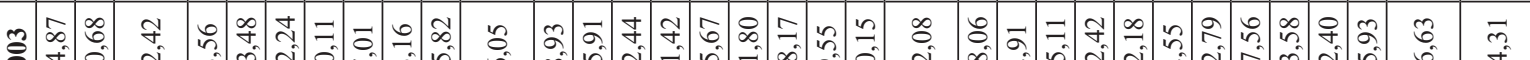

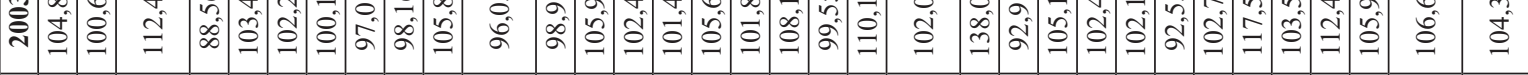
กิ సे ठे

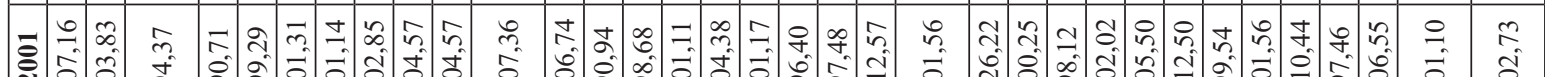

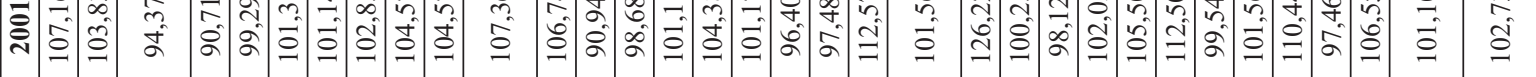
\%율 ๙ิ)

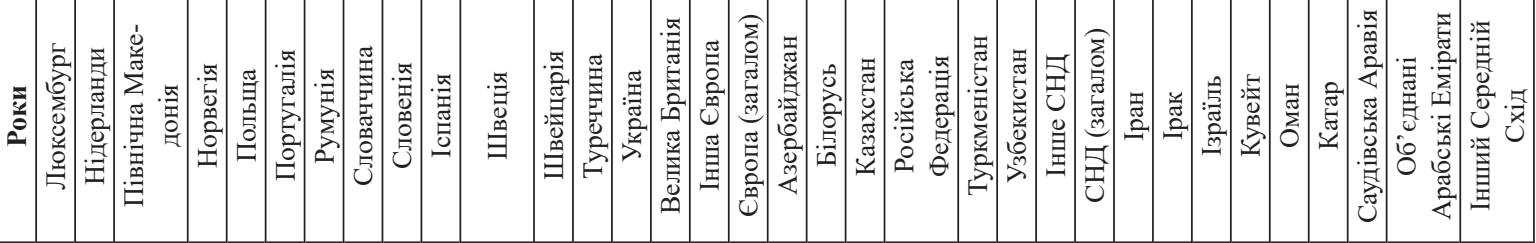


党

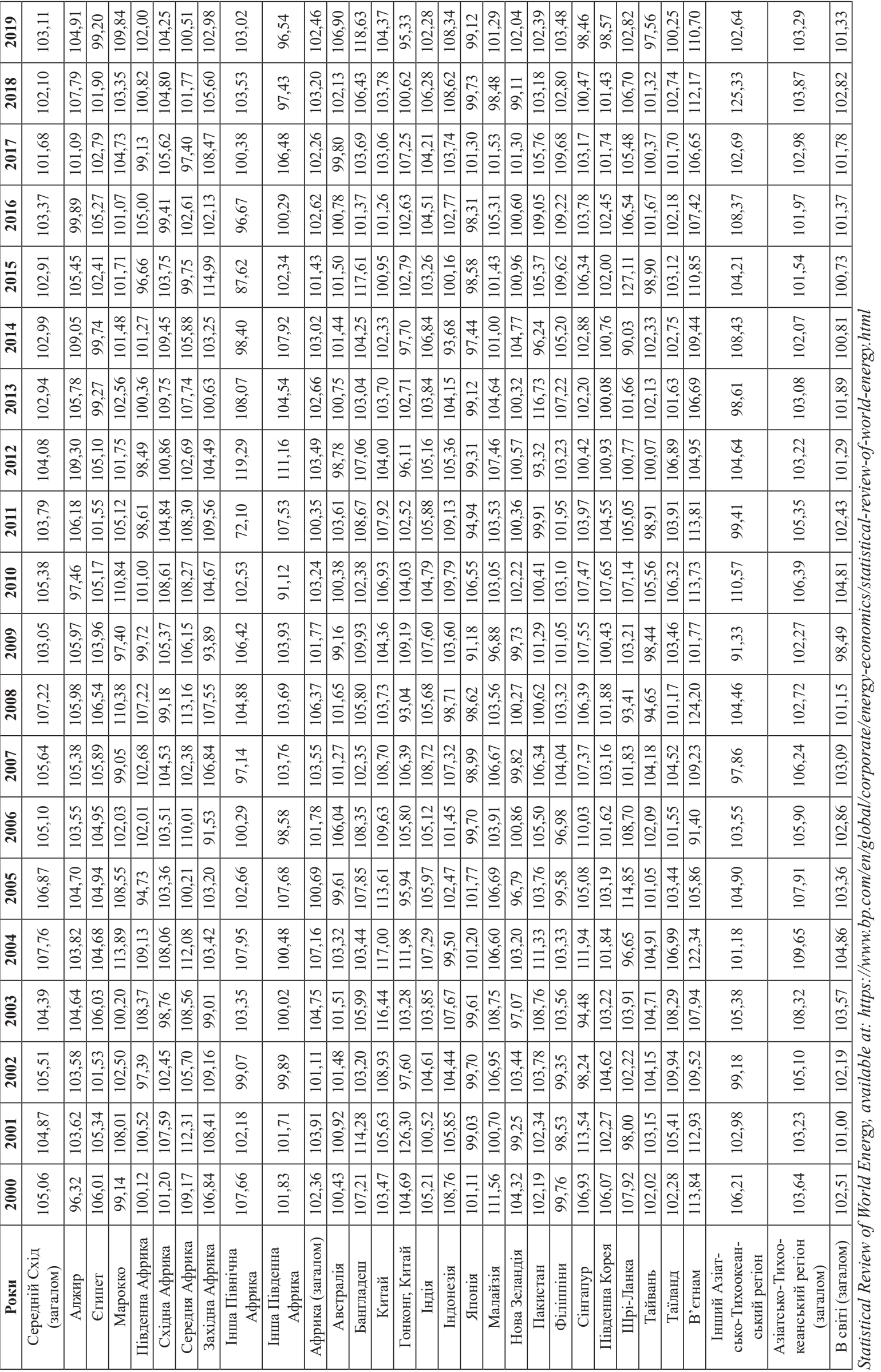




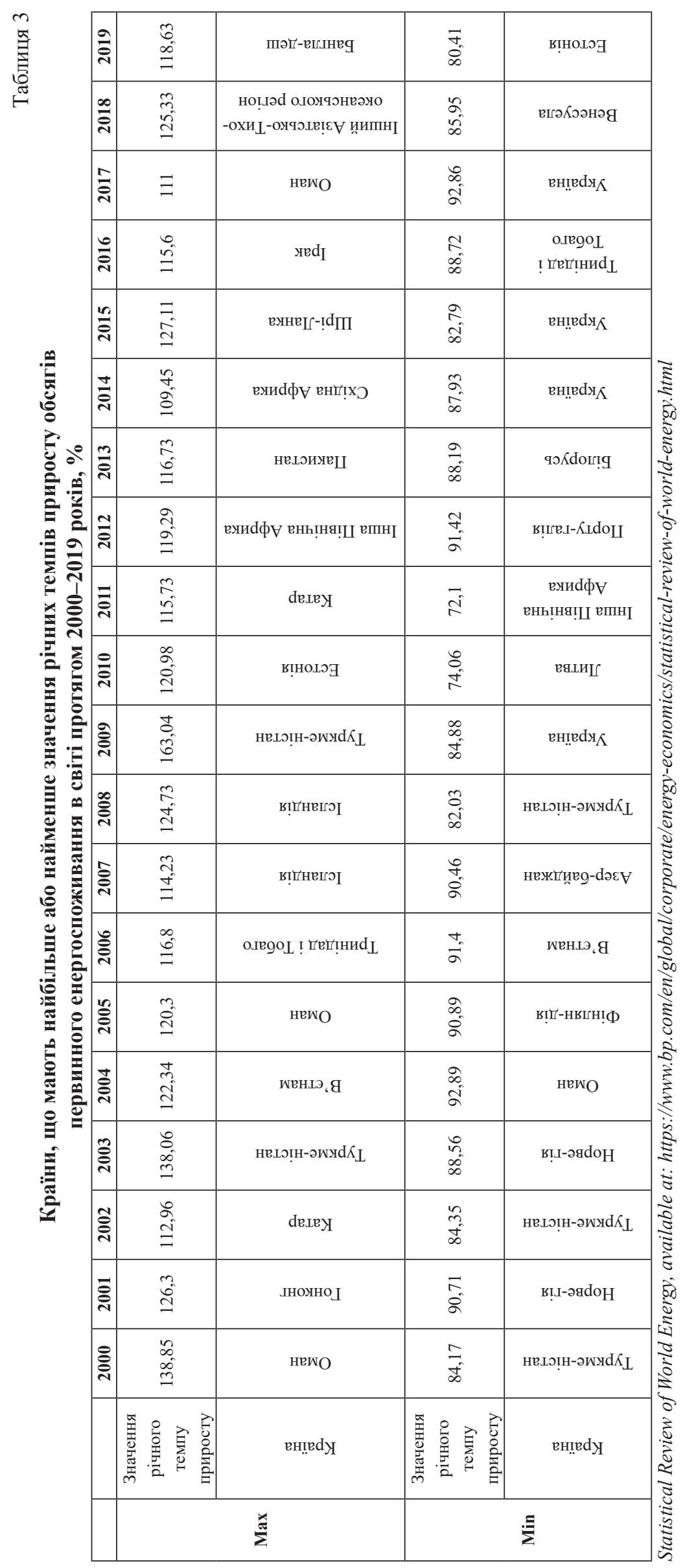


У той самий період у країнах СНД протягом 2000-2019 років (рис. 1) та темпи його приросту (табл. 2) засвідчують абсолютні та відносні зміни, що відбулися. За 2000 р. первинне енергоспоживання за даним регіоном світу становило 31,71ТВт-год, а за 2019 р. - 38,68ТВт-год (табл. 1). Порівнюючи значення за перший і останній з досліджуваних 20 років, слід відмітити, що відбулося збільшення показника на 6,97ТВт-год або на 21,98 \% по відношенню до показника за 2000 рік.

Відбулося збільшення даних показників у Північній Америці протягом 2000-2019 років (рис. 1) та темпи його приросту (табл. 2) засвідчують абсолютні та відносні зміни, що відбулися. За 2000 р. первинне енергоспоживання за даним регіоном світу становило 113,81 ТВт-год, а за 2019 р. - 116,58ТВт-год (табл. 1). Порівнюючи значення за перший і останній з досліджуваних 20 років, слід відмітити, що відбулося збільшення показника на 2,77 ТВт-год або на 2,43 \% по відношенню до показника за 2000 рік.

Динаміка первинного енергоспоживання в Південній та Центральній Америці протягом 2000-2019 років (рис. 1) та темпи його приросту (табл. 2) засвідчують абсолютні та відносні зміни, що відбулися. За 2000 р. первинне енергоспоживання за даним регіоном світу становило 20,17 ТВт-год, а за 2019 р. - 28,61 ТВт-год (табл. 1). Порівнюючи значення за перший і останній з досліджуваних 20 років, слід відмітити, що відбулося збільшення показника на 8,44 ТВт-год або на 41,84 \% по відношенню до показника за 2000 рік.

Найбільше занепокоєння викликає і становить реальну загрозу енергетичній системі зростання стрімке первинного енергоспоживання у країнах Середнього Сходу та Азійсько-Тихоокеанському регіоні.

Динаміка первинного енергоспоживання на Середньому Сході протягом 2000-2019 років (рис. 1) та темпи його приросту (табл. 2) засвідчують абсолютні та відносні зміни, що відбулися. За 2000 р. первинне енергоспоживання за даним регіоном світу становило 17,29ТВт-год, а за 2019 р. - 38,78ТВт-год (табл. 1). Порівнюючи значення за перший і останній з досліджуваних 20 років, слід відмітити, що відбулося збільшення на 21,49ТВтгод або в 1,29 рази по відношенню до показника за 2000 рік. Простежується чітка тенденція до зростання даного показника протягом досліджуваного періоду, жоден з проаналізованих 20 років не відзначився зменшенням темпів його приросту порівняно до попереднього періоду. Загалом щодо абсолютного значення первинного енергоспоживання на Середньому Сході можемо говорити про стабільне його збільшення протягом останніх 20 років (2000-2019 роки), що у відносному вираженні складає в 1,29 рази.

Динаміка первинного енергоспоживання в Азійсько-Тихоокеанському регіоні протягом 2000-2019 років (рис. 1) та темпи його приросту (табл. 2) засвідчують абсолютні та відносні зміни, що відбулися. За 2000 р. первинне енергоспоживання за даним регіоном світу становило 112,55 ТВт-год, а за 2019 р. - 257,56 ТВт-год (табл. 1). Порівнюючи значення за перший і останній з досліджуваних 20 років, слід відмітити, що відбулося збільшення показника на 145,01 ТВт-год або в 1,29 рази.Простежується чітка тенденція до зростання даного показника протягом досліджуваного періоду, жоден із проаналізованих 20 років не відзначився зменшенням темпів його приросту порівняно до попереднього періоду. Загалом первинне енергоспоживання в Азійсько-Тихоокеанському регіоні за 2019 рік зросло в 1,29 рази порівняно з аналогічним показником за 2000 рік, що є найвищим показником змін в порівнянні зі змінами у інших регіонах світу.

Вищевказані показники засвідчують, що надалі важливим питанням глобального рівня залишатиметься управління та ефективне застосування регуляторних механізмів у енергетичній безпеці світу.

Висновки дослідження. Тому досягненню глобальної енергетичної безпеки сприятиме реалізація світовим співтовариством системи заходів у трьох основних напрямках: надійне забезпечення світової економіки традиційними видами енергоресурсів; ріст ефективності використання енергетичних ресурсів і захист навколишнього середовища; розробка й використання нових джерел енергії.

Незважаючи на різницю в підходах окремих держав, існують можливості зближення в розумінні енергетичної безпеки. Енергетична безпека - це взаємна відповідальність споживача й постачальника енергетичних ресурсів. Це визнають всі, однак проблеми починаються там, де споживач і постачальник починають вимагати один від одного гарантій поставок або оплати цих поставок. Незважаючи на обмежене число країн - постачальників енергетичних ресурсів, між ними існує конкуренція. Фактором, що іiї стимулює, є принцип енергетичної безпеки - диверсифікованість поставок до країни-споживача. Конкуренція за споживача, побудована на економічних принципах, є логічним і зрозумілим явищем.

Також важливим завданням $є$ широке запровадження енергоефективності на міжнародному рівні як основного пріоритету енергетичних стратегій. Заощадження енергоресурсів - найбільш рентабельний і екологічно відповідальний спосіб забезпечення зростаючого попиту на енергію. Зусилля по підвищенню енергоефективності та енергозбереження сприяють зниженню енергоємності економічного розвитку, зміцнюючи тим самим глобальну енергетичну безпеку. Підвищення енергоефективності та економія енергії дозволяють знизити навантаження на інфраструктуру, сприяють оздоровленню навколишнього середовища за рахунок скорочення викидів парникових газів і забруднюючих речовин.

Пріоритетні кроки в цій області містять у собі: підвищення рівня екологічності та ефективності переробки вуглеводнів; зниження до мінімального рівня спалювання попутного газу в смолоскипах і заохочення його вико- 
ристання; удосконалювання енергетичної інфраструктури, у тому числі мінімізація втрат нафти та нафтопродуктів при транспортуванні, витоку газу із систем газопостачання; утилізація метану, що утвориться в результаті видобутку вугілля.

Отже, енергоресурси мають критично важливе значення для поліпшення якості життя й розширення можливостей, що відкриваються перед громадянами світу. Тому забезпечення ефективного, надійного й екологічно безпечного енергопостачання за цінами є викликом для всього людства. Для виконання цього всеосяжного завдання необхідно вирішити ряд серйозних і взаємозалежних проблем, таких як: високі й нестійкі ціни на нафту; зростаючий попит на енергоресурси; зростаюча залежність багатьох країн від імпорту енергоносіїв; потреба у величезних інвестиціях в усі ланки енергетичного ланцюжка; необхідність захисту навколишнього середовища й рішення проблеми кліматичних змін; уразливість життєво важливої енергетичної інфраструктури; політична нестабільність, природні катаклізми й інші погрози. У зв'язку із глобальним характером цих проблем і зростаючою взаємозалежністю між країнами-виробниками, транзитними країнами й державами- споживачами необхідно розвивати партнерські відносини з метою зміцнення глобальної енергетичної безпеки. Кращий спосіб домогтися намічених цілей у цій сфері - формування прозорих, ефективних і конкурентних світових енергетичних ринків. Важливу роль у рішенні глобальних енергетичних проблем грають національні уряди й відповідні міжнародні організації.

Для забезпечення адекватного енергопостачання у світовому масштабі необхідно в період до 2030 р. вкласти не трильйони доларів США в усі ланки енергетичного ланцюга, причому значна частина цієї суми повинна піти на потреби країн, що розвиваються. Йдеться про відбудову глобального виробничо-збутового енергетичного ланцюга з метою: подальшого енергозбереження за рахунок мер впливу на попит, а також впровадження передових видобувних та енергозберігаючих технологій; методів, у тому числі зі зберігання вуглекислого газу; заохочення до широкого використання поновлюваних і альтернативних джерел енергії; нарощування обсягу доведених запасів вуглеводнів темпами, що випереджають їхнє виснаження, і підвищення віддачі родовищ; підвищення ефективності нафто- і газовидобутку, а також розробки родовищ континентального шельфу; створення, збільшення й підвищення ефективності потужностей у нафто- і газопереробці та нафтохімії; розвиток глобального ринку зрідженого природного газу; створення або модернізації інфраструктури для транспортування й зберігання енергоносіїв; розвитку ефективних потужностей в електроенергетиці; розширення й підвищення ефективності, безпеки та надійності електромереж, їхнє з'єднання в єдину мережу.

\section{Список використаних джерел:}

1. Власюк О., Бодрук О., Ожеван М., Парахонський Б., Прейгер Д. Україна в системі міжнародної безпеки : монографія ; Національний інститут проблем міжнародної безпеки. Київ : НІПМБ, 2011.

2. Гальчинський А. Україна: стратегічні пріоритети. Аналітичні оцінки. Київ, 2003.

3. Глобалізація і сучасний міжнародний процес / За заг ред. проф.. Б. Гуменюка і проф. С. Шергіна. Київ : Університет Україна, 2009.

4. Тодоров I. Свропейська безпека: сучасний стан та перспективи для України. Вісник інформаційного иентру НАТО Прикарпатського наџіонального університету ім. В. Стефаника. 2009. № 1.

5. Федуняк С.Г. Свропейські виміри безпеки на пострадянському просторі. Формування інтегрованої системи безпеки Заходу і Нових незалежних держав ; Чернівецьк. нац. ун-т ім. Ю. Федьковича. 2005.

6. Фурашев В.М., Джердж С.Ф., Національна безпека України: шляхи забезпечення, роль і місце суспільства. Євроатлантичний курс. Київ : «Синопсис», 2009.

7. Global Economic Prospects. Economic Implications of Remittances and Migration. The International Bank for Reconstruction and Development. The World Bank, 2006.

8. Kaletsky A. Analyzing the Key Economic and Political Dynamics of the Global Economy \& They Might Impact The World's Energy Markets. 12 th European Gas Conference Flame 2006. Amsterdam 14 March 2006.

9. Saghir J. Energy and Poverty Myths, Energy and Mining Sector Board. Energy Working Notes. 2005. № 4.

10. World Energy Outlook 2005. International Energy Agency. Paris, 2005.

\section{References:}

1. Vlasiuk O., Bodruk O., Ozhevan M., Parakhonskyi B. and Preiher D. (2011), Ukraina v systemi mizhnarodnoi bezpeky [Ukraine in the international security system] Monograph, Press Natsionalnyi instytut problem mizhnarodnoi bezpeky, Kyiv. [Ukraine]

2. Halchynskyi A. (2003). Ukraina: stratehichni priorytety. Analitychni otsinky [Ukraine: strategic priorities. Analytical overview], Press Kyiv. [Ukraine]

3. Edited by prof. Humeniuka B. and prof. Sherhina S. (2009). Hlobalizatsiia i suchasnyi mizhnarodnyi protses [Globalization and modern international process], Press Universytet Ukraina, Kyiv.

4. Todorov I. (2009), "Yevropeiska bezpeka: suchasnyi stan ta perspektyvy dlia Ukrainy" ["European security: current state and foresights/prospects for Ukraine"], NATO Information Centre of Vasyl Stefanyk Precarpathian journal (Visnyk informatsiinoho tsentru NATO Prykarpatskoho natsionalnoho universytetu im. V.Stefanyka.), vol. 1. [Ukraine] 
5. Feduniak S. H. (2005), Yevropeiski vymiry bezpeky na postradianskomu prostori. Formuvannia intehrovanoi systemy bezpeky Zakhodu i Novykh nezalezhnykh derzhav [European security dimensions in the post-Soviet space. Formation of an integrated security system of the West and Newly independent states]. Press Yuriy Fedkovych Chernivtsi national University. [Ukraine]

6. Furashev V.M. and Dzherdzh S.F. (2009) Natsionalna bezpeka Ukrainy: shliakhy zabezpechennia, rol i mistse suspilstva. Yevroatlantychnyi kurs [National security of Ukraine: performance bonds and community role. Euro-Atlantic course], Press «Synopsys», Kyiv. [Ukraine]

7. The World Bank (2006), Global Economic Prospects. Economic Implications of Remittances and Migration. The International Bank for Reconstruction and Development.

8. Kaletsky A. (2006), Analyzing the Key Economic and Political Dynamics of the Global Economy \& They Might Impact The World's Energy Markets. 12 th European Gas Conference Flame 2006 [Amsterdam].

9. Saghir J.(2005), Energy and Poverty Myths, Energy and Mining Sector Board. Energy Working №tes. № 4.

10. International Energy Agency (2005), World Energy Outlook 2005 [Paris]. 